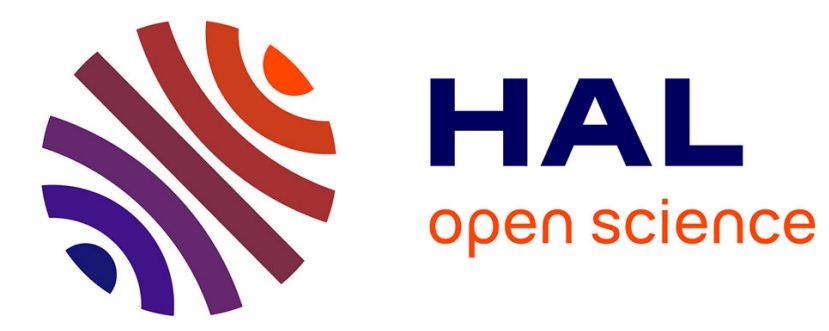

\title{
Simulating incomes of radical organic farms with MERLIN: A grounded modelling approach for French microfarms
}

Kevin Morel, Magali San Cristobal, Jean-Francois Léger

\section{- To cite this version:}

Kevin Morel, Magali San Cristobal, Jean-Francois Léger. Simulating incomes of radical organic farms with MERLIN: A grounded modelling approach for French microfarms. Agricultural Systems, 2018, 161, pp.89-101. 10.1016/j.agsy.2017.08.006 . hal-02939224

\section{HAL Id: hal-02939224 \\ https: / hal.inrae.fr/hal-02939224}

Submitted on 15 Sep 2020

HAL is a multi-disciplinary open access archive for the deposit and dissemination of scientific research documents, whether they are published or not. The documents may come from teaching and research institutions in France or abroad, or from public or private research centers.
L'archive ouverte pluridisciplinaire HAL, est destinée au dépôt et à la diffusion de documents scientifiques de niveau recherche, publiés ou non, émanant des établissements d'enseignement et de recherche français ou étrangers, des laboratoires publics ou privés. 


\section{Simulating incomes of radical organic farms with MERLIN: A}

\section{2 grounded modeling approach for French microfarms}

\section{Abstract}

Microfarms are commercial soil-based market gardens that cultivate less than 1.5 ha of organic vegetables per farmer in rural France. They seek to make a living on small acreage by using innovative strategies that combine high land-use intensity with low input and few mechanized practices, and directly sell a wide range of vegetables. Few academic studies have focused on microfarms. Our research objective was to build a simulation model of microfarms income and agricultural area based on farmers' expertise. The originality of our approach that we coined as "grounded modeling" (Glaser and Strauss, 2009) was to implement an interactive development pipeline based on inductive qualitative analysis and farmers' participation to collect data, build and validate a model adapted to the specificity of microfarms, rather than using pre-existing models. Based on extensive data collection and interactions with 20 microfarms, we built a stochastic simulation model (MERLIN) at the farm level, which combined (i) two mixed models to predict yields and workload according to farming practices for 50 crops, and (ii) a crop-planning model. One major innovation of the MERLIN model is to generate cropping plans that match the complex and temporal commercial requirements for direct selling of vegetable boxes through community-supported agricultural schemes. The model was validated based on a case-study designed with microfarmers which involved different sets of strategic choices ( 3 technical systems, 2 marketing strategies, 3 investment hypotheses), climate (mild or cold) and chosen annual workload (1,800h; 2,500h or 3,000h). Our model was judged relevant and legitimate by agricultural practitioners because it was not prescriptive and it simulations combined different types of strategies in accordance with a global approach favored by organic farmers. Grounded modeling is a promising method to create generic knowledge specifically adapted to radical organic farming systems. However, 
the epistemological implications of grounded modeling require further investigation, which may benefit from the transdisciplinary framework developed in agroecological studies.

Keywords: Agroecology; Participatory modelling; Short supply chains; Crop planning;

Horticulture

\section{Introduction}

The economic viability of radical organic farming systems (ROFS) has been infrequently investigated. ROFS are based on the historical roots of organic agriculture, which go far beyond technical issues and promote small-scale farming to maintain rural employment, alternative commercial strategies such as short supply chains to foster local economies and create social links between consumers, and do-it-yourself approaches to enhance the farmer's autonomy (Besson, 2011).

Organic market gardening microfarms in France (hereafter called microfarms) are good examples of ROFS. They have been characterized by Morel and Léger (2016) as commercial farms that meet the following four criteria: (1) soil-based market gardening is the main incomegenerating activity (excludes roof-top gardening, although part of the cultivated acreage can be protected under cold tunnels); (2) a high level of cultivated biodiversity is grown organically, with 30 to 80 vegetables and herbs (excludes mushroom and fruit production); (3) the utilized agricultural area is less than 1.5 ha by full-time equivalent, which is the minimal size generally recommended by French official agricultural development agencies for diversified market gardening (GAB/FRAB, 2009); and (4) farmers sell their produce directly to consumers primarily through vegetables boxes in community-supported agriculture (CSA) schemes where customers pay one year in advance weekly vegetables boxes which are expected to contain an assortment of seasonally available produce all over the productions season. Agricultural teachers and extension agents have observed the growing popularity of microfarms in France, first in rural areas and now also in urban areas where space is limited. No specific statistics 
51

about microfarms have been collected, but a study reported that approximately one-third of 3,000 new farms in France were created by young people with no agricultural background (Jeunes Agriculteurs, 2013). These new farmers are attracted by organic agriculture (63\%), short supply chains (58\%), and market gardening (23\%) which is the type of production attracting the highest number of people.

Microfarmers claim that they can be economically successful despite their small size (Fortier, 2014; Hervé-Gruyer and Hervé-Gruyer, 2016) thanks to a wide range of strategies including low-input practices (external commercial fertilizers and phytosanitary products are limited), high cropping densities, and limited mechanization. Young farmers who do not take over the family farm are often very enthusiastic about microfarms because they require little land and a low level of capital investment. However, the economic viability of microfarms has not been evaluated by research.

Little data is available for ROFS, and microfarms are still atypical initiatives. This precludes statistical approaches to analyze their economic viability. We assumed that computational modeling and in silico experiments could facilitate the investigation of a wide range of ROFS scenarios following a logic of in silico experimentation (Martin et al., 2011). A microfarm model should integrate alternative marketing and investment strategies in addition to technical details. Developing ROFS models is technically challenging because of the lack of fundamental data and academic knowledge about their farming practices. Radical organic farmers often do not trust top-down approaches, which can lead to invalidation of models generated without their expertise (Cash et al., 2003).

Our research objective was to build and validate a simulation model of microfarms income and agricultural area based on farmers' expertise. We developed a static stochastic simulation model at the farm level called MERLIN (Microfarms: Exploratory Research on Labor and Income), which was based on data from 20 microfarms in northern France. The originality of 
our approach that we coined as "grounded modeling" (Glaser and Strauss, 2009) was to implement an interactive development pipeline based on inductive analysis and farmers' participation to collect data, build and validate a model adapted to the specificity of microfarms, rather than using pre-existing models.

\section{Materials and methods}

\subsection{Overall description of the grounded modeling approach}

The research process ran from 2014 to 2016 and was designed investigate the question of microfarms viability. In the first step described by Morel and Léger (2016), 1-day comprehensive interviews were carried out on 20 microfarms to understand microfarmers' objectives and practices. Qualitative inductive analysis of this material collected in 2014 (Miles and Huberman, 2010) highlighted that the viability of microfarms involved both material aspects (incomes, workload) and immaterial aspects (quality of life, autonomy, meaning) and that 6 major strategic choices impacting microfarms viability: community integration, investment, marketing, technical system, labor organization, spatial and temporal organization of cultivated biodiversity. During 3 group workshops and individual discussions (for 5 microfarmers out of 20 who could not attend the workshops), farmers judged that it would be relevant for them and future microfarmers to develop a tool for decision support focusing on material aspects (incomes and workload) which raised the strongest doubts and questions among them. They showed a strong interest in developing a model to simulate incomes and agricultural area according to workload and contrasted strategic choices. Three types of strategic choices out of 6 were considered by farmers especially relevant to investigate economic aspects: technical system, marketing and investment.

Existing biophysical mechanistic crop models that focus primarily on cereals (Jones et al., 2003; Keating et al., 2003; Brisson et al., 2004) are not suited to the broad diversity of vegetables grown by microfarms. Although some information is available on the effect of low- 
101 input practices on the economics of different farming systems (Pimentel et al., 1989; Clark et al., 1999), the effect of low investment strategies through do-it-yourself approaches often promoted by microfarmers have not been quantified. Microfarmers were really enthusiastic about the possibility to run a high number of simulations in order to "take distance" from their daily reality and the limited number of existing microfarms. They were interested in testing

106 different cropping plans because crop planning was perceived as a major challenge. Indeed, microfarmers sell boxes of vegetables on a weekly basis, and their main objective is to provide a diverse selection of produce throughout the marketing season to maximize customer loyalty. Existing crop planning and land-use models optimize yields or incomes while minimizing environmental impacts (Dogliotti et al., 2005; Dury et al., 2012) but these models do not

111 adequately simulate the complex and temporal commercial requirements in short supply chains 112 (Aubry et al., 2011). To develop a tool adapted to the specific needs of microfarmers, we could not rely on current agronomic models. We decided to develop on original model based on the expertise of microfarmers as is done in participatory modelling approaches (Voinov and Bousquet, 2010).

To develop the conceptual architecture of MERLIN, we did not directly engage the microfarmers, which deviated from some participatory modelling approaches in which tools such as diagrams, cognitive maps, or software are developed that allow the stakeholders to design the model (Mendoza and Prabhu, 2006; Etienne et al., 2011). Microfarmers were involved in sharing their experience in 3-hours semi-structured interviews which were carried 121 out on 20 microfarms in 2014 and 2015 and that we hold as form of participation through 122 consultation (Pretty, 1995). The main themes discussed in interviews were how and in which way technical system, marketing and investment could impact incomes and agricultural area.

124 The collected material was processed following a method of inductive qualitative analysis, 125 which is classic in grounded research (Glaser and Strauss, 2009), using thematic coding and 126 matrix tools described by Miles and Huberman (1984). More and more abstract categories were 
127 built on the basis of an iterative cross analysis of interview content and to reveal relations 128 between these categories.

129 This analysis resulted in the conceptual architecture of MERLIN (Fig. 1) and showed that

130 technical system impacted yields and production workload per crop, investment impacted costs 131 and production workload (as self-building of equipment could raise workload) and that 132 agricultural area and production on the farm were linked to crop planning that was designed to 133 fulfill the specific requirements of direct-selling and the level of annual workload. To predict 134 yields and workload, mixed models were built based on farm data collected in 2016 from a reduced sample of 10 microfarms (described later) due to time constraints. To simulate crop

136 planning adapted to direct selling, a specific sub-model was designed (detailed later) based on

137 cropping cycles collected on this sample and marketing criteria that were developed based on 138 farmers' expertise in a collective workshop with 3 farmers in winter 2015 and validated by all 139 microfarmers of the sample.

140 To validate the modelling outputs, we used the MERLIN model in a case-study to simulate

141 incomes and agricultural area according to different set of strategic choices, climate and chosen 142 annual workload. The modalities of input variables, including 3 possible technical systems, 2 143 marketing strategies and 3 investment hypotheses were designed with 6 farmers during a 2144 hours collective workshop in 2015 (and validated afterward by all farmers of the sample) to 145 represent contrasted strategic options which raised questions about economic efficiency and 146 required land among microfarmers and people interested in starting a microfarm.

\section{2.2. Conceptual architecture of the model}

148 The MERLIN model was developed at the farm level considering that the goal of the

149 farming systems was to guarantee a quantity and diversity of produce to sell throughout the 150 marketing season in a CSA scheme. Our model combined three sub-models. Sub-model 1

151 (SM1) predicted yields per unit surface area $\left(\mathrm{kg} \cdot \mathrm{m}^{-2}\right)$ for 50 crops depending on farming practices. Sub-model 2 (SM2) predicted production workload per unit surface area $\left(\mathrm{h} \cdot \mathrm{m}^{-2}\right)$ for 
15350 crops depending on farming practices and investment strategies. Sub-model 3 (SM3)

154 generated yearly cropping plans to meet the requirements of the marketing strategy; cropping

155 plans refer to the acreage occupied by all crops every year, their temporal allocation and their

156 distribution within the farm (Dury et al., 2012). MERLIN combined these three models and the

157 other elements presented in Fig. 1 to simulate income and agricultural area utilized for a single

158 farm according to the level of chosen annual workload. 


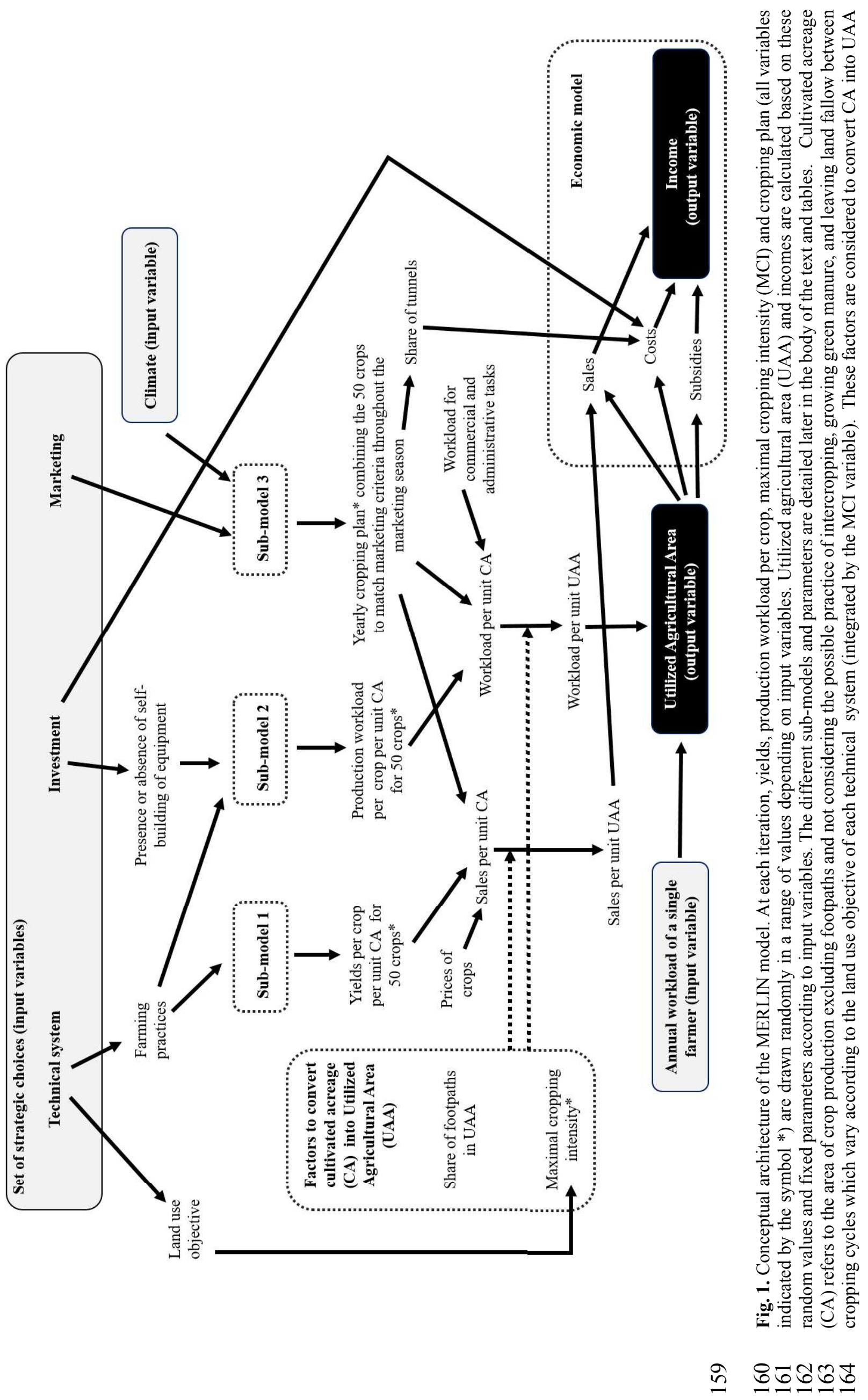


165

166

167

168

169

170 involved in building the conceptual architecture of MERLIN. The 10 microfarms were selected

171 according to theoretical sampling (Eisenhardt, 1989), and ensuring that they represented

172 microfarm diversity for four farming practice variables that potentially affect yields and

173 production workload (Table 1). We visited each of the 10 microfarms an average of four times

174 during one year to collect data. 
176 Characteristics of the 10 microfarms used to calibrate the model.

Farming practice variables

\begin{tabular}{|c|c|c|c|c|c|c|c|c|}
\hline Farm & Region & $\begin{array}{l}\text { Age } \\
\text { of } \\
\text { farm } \\
(\mathbf{y r}) \\
\end{array}$ & $\begin{array}{l}\text { UAA per } \\
\text { full time- } \\
\text { equivalent } \\
\left(\mathbf{m}^{2}\right) *\end{array}$ & $\begin{array}{l}\text { UAA } \\
\text { under } \\
\text { tunnels } \\
\left(\mathbf{m}^{2}\right) \\
\end{array}$ & $\begin{array}{l}\text { Mechaniz } \\
\text { ation** }\end{array}$ & $\begin{array}{l}\text { Low- } \\
\text { input } \\
\text { practices } \\
* * *\end{array}$ & $\begin{array}{l}\text { Intercropping } \\
* * * *\end{array}$ & $\begin{array}{l}\text { Self-built } \\
\text { equipment } \\
* * * * *\end{array}$ \\
\hline A & Brittany & 3 & 8,000 & $13 \%$ & $\mathrm{~T}$ & Yes & Yes & No \\
\hline B & Brittany & 5 & 4,300 & $19 \%$ & $\mathrm{Me}$ & No & No & No \\
\hline $\mathrm{C}$ & $\begin{array}{l}\text { Pays de la } \\
\text { Loire } \\
\end{array}$ & 5 & 8,000 & $10 \%$ & $\mathrm{Me}$ & No & No & No \\
\hline $\mathrm{D}$ & $\begin{array}{l}\text { Pays de la } \\
\text { Loire } \\
\end{array}$ & 4 & 3,000 & $18 \%$ & M & Yes & No & No \\
\hline $\mathrm{E}$ & $\begin{array}{l}\text { Centre-Val } \\
\text { de Loire }\end{array}$ & 2 & 1,800 & $9 \%$ & M & Yes & No & Yes \\
\hline $\mathrm{F}$ & Normandy & 9 & 1,250 & $48 \%$ & M & Yes & Yes & No \\
\hline G & Normandy & 4 & 8,000 & $10 \%$ & $\mathrm{Me}$ & Yes & No & Yes \\
\hline $\mathrm{H}$ & Lorraine & 4 & 3,500 & $23 \%$ & $\mathrm{~T}$ & Yes & No & Yes \\
\hline I & Lorraine & 5 & 8,500 & $18 \%$ & $\mathrm{~T}$ & No & No & No \\
\hline $\mathrm{J}$ & Lorraine & 4 & 3,500 & $25 \%$ & $\mathrm{~T}$ & Yes & No & No \\
\hline
\end{tabular}

* Utilized agricultural area dedicated to market gardening includes footpaths between the cropping beds but not the area dedicated to buildings or access roads. Full-time equivalent was estimated by farmers and corresponds to an average workload from $35-50 \mathrm{~h}$ per week.

** Mechanization: M, manual labor for all farming activities including superficial tillage; T, mechanization only for tillage, mainly practiced with a tiller; Me, mechanization for most farming practices (tractor) except for some hand-harvesting.

*** Low-input practices: Include a variety of practices such as straw mulching, green manure, preparing farmmade phytosanitary preparations, and composting animal manure freely available from local organic or conventional cattle breeders. "Yes" means that farmers implemented as much as possible such practices to reduce the costs of commercial inputs whereas "No" means that farmers preferred generally to buy commercial inputs to make work easier and faster (results from the qualitative analysis of interviews).

**** Intercropping: Two to five crops are grown together and carefully chosen to have complementary heights to maximize incident light, different rooting depths to maximize water and nutrient absorption, and different maturation times to limit competition between plants (De Liedekerke De Pailhe, 2014).

***** Self-built equipment: Farmers construct as many tools, equipment, and farm buildings as possible, from previously used or free materials (do-it-yourself approach).

\subsubsection{Calculating average marketable yields}

For each farm, mean yields $\left(\mathrm{Y}\right.$, in $\left.\mathrm{kg} \cdot \mathrm{m}^{-2}\right)$ were calculated for the 50 most common crops grown by microfarmers (Table 2). We calculated marketable yields, which accounted for field 
198

tunnels and outdoors areas). For crops with several harvests and sales during a cropping cycle, cumulative sales were calculated to determine the total sales attached to a cropping cycle. Marketable yields were calculated by dividing the sales with their corresponding cultivated acreage excluding footpaths.

\subsubsection{Estimating production workload for each crop}

Most farmers did not have records for the workload dedicated to each crop. Therefore, we estimated the average production workload per unit area of cultivated acreage $\left(\mathrm{Wp}\right.$, in $\mathrm{min} \cdot \mathrm{m}^{-}$ ${ }^{2}$ ) for each crop on each farm according to the procedure of Morel (2016; pp. 282-284), which was based on farmer's expert knowledge. Farmers estimated their production workload over the year considering the frequency of 'light weeks,' 'regular weeks,' and 'busy weeks.' The global annual workload was then allocated to each crop based on its respective acreage and a categorization made by farmers of their crops (

Fig. 2) according to the workload required ('light,' 'regular,' or 'heavy') for the three phases of the production cycle (setting up, managing, and harvesting the crop).

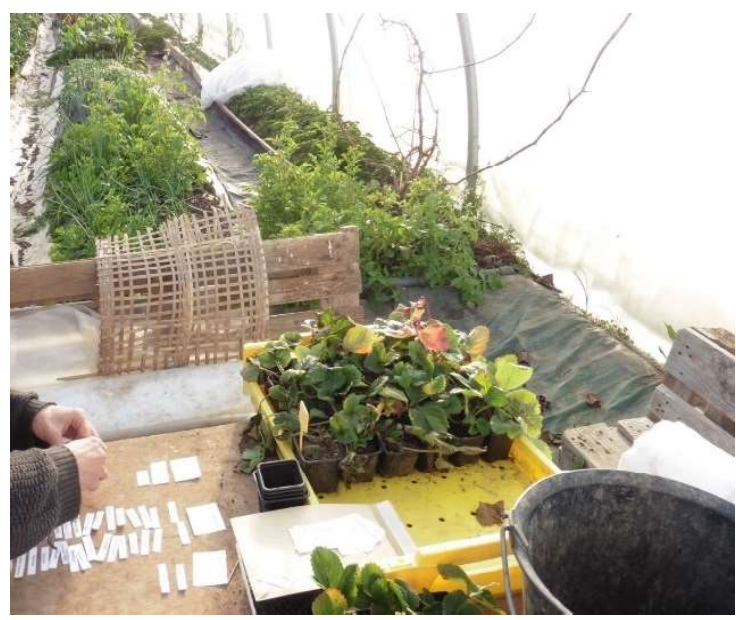

Fig. 2. Farmer categorizing the workload of his crops for a specific stage of the production cycle (here, the settingup stage). Each piece of paper represents a crop that the farmer categorizes in three columns (light, regular, or heavy workload) based on his expertise. 


\subsubsection{Creating a database of cropping cycles}

Cropping plans were generated to combine cycles of different crops over the year. A cropping cycle was defined by the planting month and harvesting period (in months) for a specific crop. Cropping cycles were distinguished for two locations (outside field or unheated tunnels) and two climatic zones (cold or mild climate). The cold climate referred to the Lorraine and Normandy areas (mean monthly minimum temperature, $0^{\circ} \mathrm{C}$ in winter and $13^{\circ} \mathrm{C}$ in summer; mean monthly maximum temperature, $6.5^{\circ} \mathrm{C}$ in winter and $24^{\circ} \mathrm{C}$ in summer). The mild climate referred to Brittany, Pays de La Loire, and Centre-Val de Loire (mean monthly minimum temperature, $4^{\circ} \mathrm{C}$ in winter and $13.5^{\circ} \mathrm{C}$ in summer; mean monthly maximum temperature, $9^{\circ} \mathrm{C}$ in winter and $23^{\circ} \mathrm{C}$ in summer). The main difference between these two climates was the length of winter temperature with risk of freezing, which was an average of 6 months for the cold climate and 5 months for the mild climate.

We collected data on cropping cycles for each farm based on existing planning documents if available. Otherwise, we asked the farmer to mark a calendar with the different possible cropping cycles on the farm (Fig.3). Then, data from the 10 microfarms was synthesized to build a database of 1,053 possible cropping cycles according to all crops, locations, climates, and marketing strategies (described later). These cycles are detailed in Morel (2016; pp. 290-317). For a given crop, climate and marketing strategy, various cropping cycles were possible with different lengths according to their planting month. The number of possible cropping cycles were 5.6 in average and ranged from 1 for spring garlic for example (planted in November and harvested in March under tunnel in the 12-month marketing strategy and cool climate) to 34 for lettuce. Indeed, lettuce growing cycles could be started every month except in January, under tunnel or outside, with different growing period lengths (short cycle with one harvest or longer cycle with cut-and-come-again strategies). 
243

244

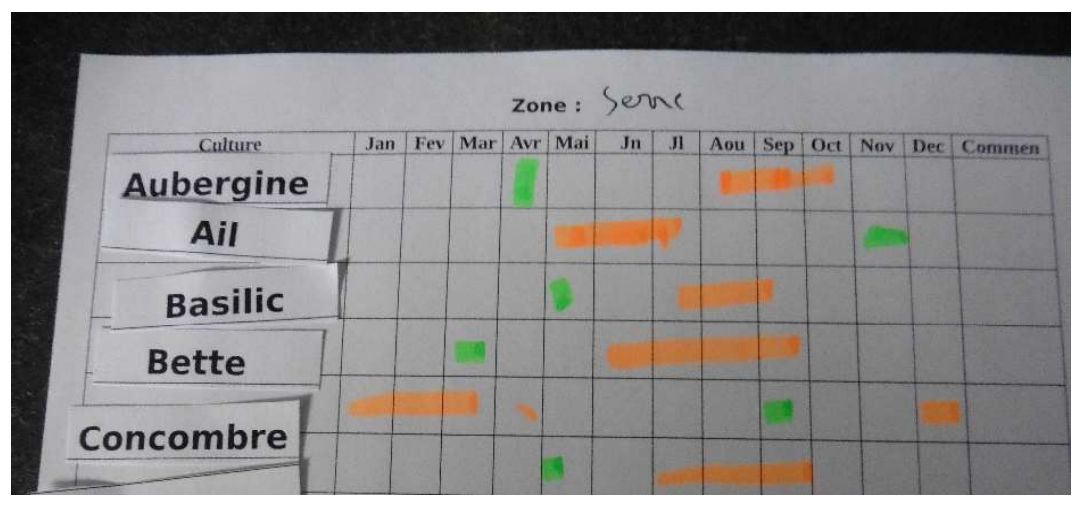

Fig. 3. Example calendar showing the cropping cycles under tunnels ("serre" in French) for a microfarm in a cold climate. The left column refers to crops (eggplant, garlic, basil, chard, and cucumber). The 12 other columns refer to the 12 months of the year. The planting period was drawn in green and the harvesting period in orange.

\subsubsection{Characterizing costs, subsidies, and prices}

The variable and fixed production costs attached to the different farming practices and investment strategies and subsidies were averages derived from all financial documents available since farm creation. The crop selling price (Table 2) was the average price from the 10 microfarms for organic vegetables sold in CSA schemes. These prices were affordable for people with lower- and middle-incomes in rural areas.

\section{Table 2}

Characteristics of the 50 crops considered in the model.

\begin{tabular}{llllllll}
\hline Crop & Crop category & $\begin{array}{l}\text { Crop } \\
\text { share } \\
(\mathbf{k g})\end{array}$ & $\begin{array}{l}\text { Price } \\
(\mathbf{E U R \cdot k g})\end{array}$ & $\begin{array}{l}\text { Effect } \\
\text { on log } \\
\text { (Yields) }\end{array}$ & $\begin{array}{l}\text { Effect on log } \\
\text { (Production } \\
\text { workload) }\end{array}$ & $\begin{array}{l}\text { Grown in } \\
\text { tunnels }\end{array}$ & $\begin{array}{l}\text { Grown } \\
\text { outdoors }\end{array}$ \\
\hline Beetroot (fresh) & Root crop & 0.80 & 3.04 & 0.18 & -0.26 & Yes & Yes \\
\hline Beetroot (storage)* & Root crop & 0.63 & 2.58 & 0.67 & -0.06 & No & Yes \\
\hline Broad bean & Fruit crop & 1.00 & 4.08 & -0.06 & -0.16 & Yes & Yes \\
\hline Broccoli & Cooked greens & 0.50 & 3.57 & -1.04 & -0.51 & Yes & Yes \\
\hline Brussels sprouts & Cooked greens & 0.50 & 4.46 & -0.66 & -0.05 & No & Yes \\
\hline Cabbage & Cooked greens & 0.81 & 2.47 & 0.53 & -0.28 & Yes & Yes \\
\hline Carrot (fresh) & Carrot & 0.58 & 3.37 & 0.42 & 0.17 & Yes & Yes \\
\hline Carrot (storage)* & Carrot & 1.00 & 2.43 & 0.67 & 0.25 & No & Yes \\
\hline Cauliflower & Cooked greens & 0.78 & 3.04 & -0.82 & -0.47 & Yes & Yes \\
\hline Celeriac (storage)* & Root crop & 0.75 & 3.02 & 0.21 & -0.15 & Yes & Yes \\
\hline Celery & Cooked greens & 0.50 & 2.63 & 0.17 & -0.37 & Yes & Yes \\
\hline Chard & Cooked greens & 0.96 & 2.68 & 0.05 & -0.34 & Yes & Yes \\
\hline Chicory & Raw greens & 0.40 & 4.5 & -0.42 & -0.73 & Yes & Yes \\
\hline Chili & Seasoning & 0.09 & 11.34 & -1.96 & -0.14 & Yes & No \\
\hline Chinese cabbage & Fruit crop & 0.70 & 4.33 & 0.29 & -0.18 & Yes & Yes \\
\hline
\end{tabular}




\begin{tabular}{|c|c|c|c|c|c|c|c|}
\hline Crop & Crop category & $\begin{array}{l}\text { Crop } \\
\text { share } \\
(\mathrm{kg}) \\
\end{array}$ & $\begin{array}{l}\text { Price } \\
(\text { EUR·kg-1) }\end{array}$ & $\begin{array}{l}\text { Effect } \\
\text { on log } \\
\text { (Yields) } \\
\end{array}$ & $\begin{array}{l}\text { Effect on log } \\
\text { (Production } \\
\text { workload) } \\
\end{array}$ & $\begin{array}{l}\text { Grown in } \\
\text { tunnels }\end{array}$ & $\begin{array}{l}\text { Grown } \\
\text { outdoors }\end{array}$ \\
\hline Cucumber & Fruit crop & 0.63 & 3.06 & 1.15 & 1.22 & Yes & Yes \\
\hline Eggplant & Fruit crop & 0.70 & 3.9 & 0.63 & 0.38 & Yes & No \\
\hline Endive & Raw greens & 1.00 & 5.76 & -0.85 & 0.02 & No & Yes \\
\hline Fennel & Cooked greens & 0.57 & 3.72 & -0.24 & -0.24 & Yes & Yes \\
\hline French bean & Fruit crop & 0.77 & 6.93 & -0.26 & -0.01 & Yes & Yes \\
\hline Garlic (storage) & Seasoning & 0.31 & 5.98 & -0.69 & -0.12 & Yes & No \\
\hline Garlic (spring) & Seasoning & 0.12 & 9.18 & -0.88 & 0.02 & Yes & Yes \\
\hline Herbs & Seasoning & 0.15 & 5.06 & -0.38 & -0.17 & Yes & Yes \\
\hline Kale & Cooked greens & 0.50 & 4 & -0.79 & -0.19 & Yes & Yes \\
\hline Kohlrabi & Cooked greens & 0.65 & 3.52 & 0.47 & -0.27 & Yes & Yes \\
\hline Lamb lettuce & Raw greens & 0.23 & 11.82 & -0.86 & 0.29 & Yes & Yes \\
\hline Leek & Cooked greens & 0.88 & 2.88 & 0.03 & 0.30 & Yes & Yes \\
\hline Lettuce & Raw greens & 0.43 & 3.16 & 0.10 & -0.42 & Yes & Yes \\
\hline Melon & Fruit crop & 0.90 & 3.51 & 0.50 & -0.12 & Yes & No \\
\hline Mixed salad leaves & Raw greens & 0.22 & 11.29 & -0.92 & 0.12 & Yes & Yes \\
\hline Onion (spring) & Seasoning & 0.53 & 3.69 & -0.22 & 0.06 & Yes & Yes \\
\hline Onion (storage) & Seasoning & 0.63 & 3.07 & 0.10 & 0.17 & No & Yes \\
\hline Parsnip & Root crop & 0.83 & 3.15 & 0.45 & 0.13 & No & Yes \\
\hline Pea & Fruit crop & 0.53 & 7.71 & -0.72 & 0.11 & Yes & Yes \\
\hline Potato (storage)* & Potato & 1.00 & 2.1 & 0.20 & 0.13 & Yes & Yes \\
\hline Potato (early) & Potato & 1.11 & 3.53 & 0.05 & 0.07 & No & Yes \\
\hline Radish (fresh) & Root crop & 0.34 & 4.92 & -0.31 & -0.28 & Yes & Yes \\
\hline Radish (storage) & Root crop & 0.60 & 2.89 & 0.28 & -0.45 & Yes & Yes \\
\hline Shallot (storage) & Seasoning & 0.24 & 5.69 & -0.42 & 0.04 & Yes & Yes \\
\hline Spinach & Cooked greens & 0.65 & 4.71 & -0.82 & 0.06 & Yes & Yes \\
\hline Squash & Fruit crop & 1.05 & 2.59 & 0.38 & -0.39 & Yes & Yes \\
\hline Strawberry & Fruit crop & 0.38 & 10.53 & -0.45 & 0.14 & No & Yes \\
\hline Sweede (storage)* & Root crop & 0.75 & 2.6 & 0.46 & -0.45 & No & Yes \\
\hline Sweet pepper & Fruit crop & 0.41 & 4.54 & 0.43 & 0.17 & Yes & Yes \\
\hline Tomato (cherry) & Fruit crop & 0.28 & 6.58 & 1.05 & 1.26 & Yes & No \\
\hline Tomato (classic) & Fruit crop & 1.33 & 3.12 & 1.66 & 1.27 & Yes & No \\
\hline Tomato (heritage) & Fruit crop & 1.25 & 3.9 & 1.07 & 1.27 & Yes & No \\
\hline Turnip (fresh) & Root crop & 0.63 & 3.18 & 0.23 & -0.29 & Yes & Yes \\
\hline Turnip (storage)* & Root crop & 0.75 & 2.64 & 0.46 & -0.45 & No & Yes \\
\hline Zucchini & Fruit crop & 1.20 & 2.55 & 0.86 & -0.10 & Yes & Yes \\
\hline
\end{tabular}

Storage, crops that can be stored.

$257 *$ Indicates winter storage crops that are not grown in the 9-months marketing strategy selling from April to

258 December, described later.

259 Crop categories are families of crops expected by consumers in their boxes. Tomatoes, carrots, and potatoes were

260 so strongly expected that they were a category as such. These categories were used by the crop-planning sub-

261 model (SM3).

262 A "crop share" is the quantity of crop required for one vegetable box (mean of 10 microfarms used in SM3 and

263 to calibrate the model). 
Effect on $\log$ (Yields) and log (Production workload) are predictions used in SM1 and SM2, respectively, in log $\left(\mathrm{kg} \cdot \mathrm{m}^{-2}\right)$ and $\log \left(\mathrm{min} \cdot \mathrm{m}^{-2}\right)$.

\subsection{Predicting yields and production workload}

\subsubsection{Developing linear mixed models}

We aimed to assess the effects of the four farming practice variables on yields and on production workload, independent of the particular farm or crop. We used linear mixed models that held the four farming practices as fixed effects and considered the farm and crop as independent random effects. The rationale behind the use of mixed models was to account for the correlation between measures on the same farm or for the same crop which were considered as nested. Moreover, considering farms and crops as random effects allowed us to predict the impact of each level of crops and farms despite the limited number of observations thanks to an effect of "shrinkage" incorporated in the mixed model approach that lowered extreme estimations. Extreme estimations could occur due do the sampling design where only one measure was performed for each crop in each farm. Hence the mixed model approach was here a method of choice.

Mixed models were built based on 387 observations of yields (Y) $\left[2.86 \pm 2.35 \mathrm{~kg} \cdot \mathrm{m}^{-2}\right.$ (SD throughout), range 0.18-13.9] and production workload (Wp) $\left(39.6 \pm 36.7 \mathrm{~min} \cdot \mathrm{m}^{-2}\right.$, range 5-23.1) for the combinations of the 10 farms and 50 crops. Depending on farms, data were collected about 30 to 48 crops. Depending on crops, data were collected on 4 to 10 farms. To obtain the required homoscedasticity of residuals, the two response variables were transformed with decimal $\operatorname{logarithm}$ to $\log (\mathrm{Y})$ and $\log (\mathrm{Wp})$. A backward selection of variables $(* p<0.05)$ led to two final parsimonious sub-models (SM). These two sub-models were SM1 (Table 3) for $\log (\mathrm{Y})$ and SM2 for $\log (\mathrm{Wp})$ (Table 4). These models were generated using lme4 in $\mathrm{R}$ version 3.3.1 (Bates, 2010). The goodness of fit was assessed with a conditional R-squared that describes the proportion of variance explained by both the random and the fixed factors. 
Table 3

Sub-model 1 (SM1), a linear mixed model for $\log (\mathrm{Y})$ [yield in $\log \left(\mathrm{kg} \cdot \mathrm{m}^{-2}\right)$ ].

\section{Fixed effects}

\begin{tabular}{lccc} 
& Estimated & Std error & $p^{* * *}$ \\
\hline Intercept* & 0.38 & 0.13 & \\
\hline Mechanization only for tillage** & 0.48 & 0.12 & $<0.0001$ \\
\hline Manual labor only** & 0.32 & 0.13 & 0.01 \\
\hline *Mechanization for most farming activities. **Discrepancy from intercept ***t-test.
\end{tabular}

$*$ Mechanization for most farming activities. **Discrepancy from intercept. ***t-test.

\section{Random effects}

\begin{tabular}{ll} 
& Variance \\
\hline Crop & $\hat{\sigma}_{C}^{2}=0.49$ \\
\hline Farm & $\hat{\sigma}_{F}^{2}=0.018$ \\
\hline Residual & $\hat{\sigma}_{e}^{2}=0.18$ \\
\hline
\end{tabular}

Goodness of fit: Conditional $\mathrm{R}^{2}=0.75$.

306 Sub-model 2 (SM2), a linear mixed model for $\log (\mathrm{Wp})$ [production workload in $\log \left(\min \cdot \mathrm{m}^{-2}\right)$ ]. 


\section{Fixed effects}

\begin{tabular}{lccc} 
& Estimated & Std error & $p^{* * *}$ \\
\hline Intercept* & 3.08 & 0.15 & \\
\hline Presence of low-input practices** & 0.47 & 0.21 & 0.03 \\
\hline Self-built equipment** & 0.51 & 0.18 & 0.004 \\
\hline Mechanization only for tillage** & -0.37 & 0.19 & 0.06 \\
\hline Manual labor only** & -0.12 & 0.23 & 0.06 \\
\hline
\end{tabular}

*Mechanization for most farming activities, absence of low-input strategies, and absence of self-built equipment. $* *$ Discrepancy from intercept. $* * * t$-test.

\section{Random effects}

\begin{tabular}{ll}
\hline Crop & Variance \\
\hline Farm & $\hat{\sigma}_{C}^{2}=0.42$ \\
\hline Residual & $\hat{\sigma}_{F}^{2}=0.042$ \\
\hline
\end{tabular}

Goodness of fit: Conditional $\mathrm{R}^{2}=0.76$.

The only significant fixed effect on yields was the level of mechanization. This value was significantly higher for "manual labor only" and "mechanization only for tillage" because they allowed higher planting density. These schemes did not implement mechanized weeding, which

312 required more space between the crop rows.

313 The significant fixed effects on production workload were the level of mechanization, the

314 presence of low-input practices, and self-built equipment. "Manual labor only" and

315 "mechanization only for tillage" led to lower workload compared with mechanization for most 316 cropping practices. Higher cropping densities reduced the workload dedicated to weeding, 317 because weeds had less space to invade crops (Liebman and Davis, 2000). Farmers who used a 318 tiller only for tillage or manual labor also tended to till the soil less frequently than farmers with

319 a tractor. The use of mechanization for tillage at the same high density of planting reduced 320 workload. Low-input practices and self-built equipment resulted in a higher workload. The 321 predicted effects for the 50 crops on $\log (\mathrm{Y})$ for yields and $\log (\mathrm{Wp})$ for production workload are 322 presented in Table 2. Intercropping did not significantly affect yields or workload. The impact of climate also was also tested, but it was not significant. 


\subsubsection{Building three coherent technical systems}

Farming practices were combined to build three coherent technical systems. For each technical system, yields and production workload estimates were based on sub-model 1 and sub-model 2 and considered the specific modality of level of mechanization, low-input practices, and intercropping. The self-built equipment variable was used to characterize the effect of investment strategies, which are described below. The three organic technical systems are (1) manual microagriculture, (2) bio-intensive market gardening and (3) classic diversified market gardening.

The manual system was designed to produce a large quantity of food on a small amount of land. The land-use objective was high, and included 2 to 6 cropping cycles per plot per year. This intense schedule relied on intercropping and excluded green manure, but implement other lowinput practices. The bio-intensive system maximized productivity per unit area by conducting high-density planting. Mechanization was used for superficial tillage. Intercropping was not practiced because it was perceived as a source of complexity in crop management. Low-input practices were implemented. The maximum number of crops were grown in one plot each year, but green manure was integrated into the rotation, which reduced the land-use objective compared with the manual system. The bio-intensive system had from 1 to 4 cropping cycles per year. The classic system was inspired by current farming practices that are common in diversified organic market gardening in France. In classic systems, mechanization was used for most cropping activities, no intercropping or low-input practices were implemented, it was not designed to optimize land use, and there were only one or two cropping cycles per plot per year.

\subsection{Modeling crop planning to match commercial requirements}

\subsubsection{Considering two marketing strategies}

Most microfarms in this study sold family-sized vegetable boxes on a weekly basis, usually with a one-season contract within the framework of CSA. The marketing season for these farms 
ranged from 9 to 12 months. Two contrasting strategies for marketing the vegetables boxes were considered in the model by varying the marketing season length and the crops sold: (1) A marketing period of 12 months modeled farmers selling a wide range of crops throughout the year, including winter storage crops. Only the first two weeks of January were reserved for holidays; (2) A marketing period of 9 months from April to December modeled farmers reserving some of the winter for holidays. Winter storage crops were not grown (Table 2).

\subsubsection{Generating random cropping plans based on marketing with sub-model 3 (SM3)}

Sub-model 3 (SM3) was a combination program developed with $\mathrm{R}$ version 3.3.1, that generated random cropping plans providing convenient diversity and quantity of crops for one family-size vegetables box throughout the marketing season, which is crucial for consumers loyalty (Navarrete et al., 2009). Based on a collective workshop with 3 farmers (whose results were validated by all farmers), crop planning criteria were modelled the following way:

- Vegetables boxes had to present every week a balance between eight categories of crops: (Appendix A). Tomatoes, carrots and potatoes were considered as a single standing category because of their importance in consumers' preferences.

- Quantity and diversity criteria were characterised for every month and each category of crop considering that 4 different vegetables boxes were sold every month. The expected quantities of crops in a weekly family-sized vegetable box varied according to the crop, and were designated as "crops shares" (Table 2). Quantity criteria were expressed in number of shares per month and diversity criteria in number of different crops present in the boxes over the month (Appendix A). For the 12-months marketing strategy, 2 weeks of holidays were considered in January which decreased the number of shares required this month. 
- A trimester diversity criteria was integrated to guarantee the diversity not only during the month but also throughout the year which was a key point in consumer loyalty. To guarantee the year-round diversity, at least 30 crops had to be marketed.

- As the diversity and quantity of crops required depended on the marketing strategy, criteria were characterised for 9-monts and 12-months marketing strategies.

- As the diversity and quantity of crops available depended on the climate, criteria were characterised for the cool and the mild climate considered in the study (Appendix A).

For each crop, the minimal number of crops shares per harvesting month (SHmin) was characterised. This minimal number of shares was based on the consideration that some crops had to be harvested various times a month and had therefore to be included various times in the vegetables boxes of the month. SHmin was 2 for eggplant, French beans, sweet peppers and tomatoes, 4 for courgettes and cucumbers and 1 for all other crops. For all crops the maximal number of crops shares per harvesting month (SHmax) was 4. SM3 selected iteratively month after month from the cropping cycles database the cropping cycles allowing a harvest during the month. Each time, a crop and a cropping cycle were randomly chosen among these possibilities and a number of shares was affected to it. If this cropping cycle had not been affected shares before, the number of shares affected was SHmin multiplied by the length of the harvest period (in months). If this cropping cycle had been affected shares before and its number of shares was less than SHmax multiplied by the length of the harvest period, the number of additional shares affected to the cropping cycle was 1 . At the end of each iteration, the average number of shares harvested per crop and per month was calculated considering that all shares of a cropping cycle were allocated homogeneously over the harvest period. The number of different crops per month was also calculated. As long as diversity and quantity criteria (Appendix A) were not respected for the month, another iteration started for the same month. If conditions were respected, SM3 stepped to the next month. At the end of the process, 

417 integrate.

trimester diversity criteria were checked. If they were not respected, the process started again from the beginning. This iterative process was run separately for each of the 8 categories of crops. Then, cropping cycles of the 8 categories of crops and their respective number of shares were aggregated. A final yearly diversity check controlled that at least 30 crops were marketed over the year.

To extend the harvest period of a crop, microfarmers combined cropping cycles with overlapping harvest periods. For example, to harvest French beans from July to September, market gardeners could combine a cropping cycle of French beans planted in March and harvested from July to August and a cropping cycle implanted in April and harvested from August to September. However, the fact that the harvests of these two cycles overlapped in August did not mean that customers received twice as many shares of French beans in August but that the shares of French beans in August came from both cropping cycles. The possibility of combining cropping cycles was integrated in SM3. Each time that a cropping cycle was randomly selected by the model, it was combined to the cropping cycles of the same crop with overlapping harvest period which had been affected shares before (if existing) to create an extended cropping cycle which was managed by the model exactly as a regular cropping cycle whose length was the extended harvest period. This way, the minimal and maximal number of shares per month applied for the combination and not for the individual cropping cycles composing it. Such combinations were not limited in the number of cropping cycles they could

18 The total number of crops shares affected at every cropping cycle was converted into cultivated acreage based on the yields predicted by SM1 (depending on farming practices) and the mean weight of shares (Table 2) as explained in Fig. 4. This resulted in a cropping plan characterized by a cultivated acreage affected to different cropping cycles running over the 
422 year. In terms of spatial allocation, the only explicit criteria considered in this cropping plan 423 was the location in the tunnel area or in the outside field attached to each cropping cycle. 
กิ

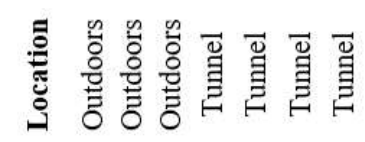

응 8

훙

可

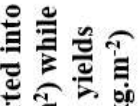

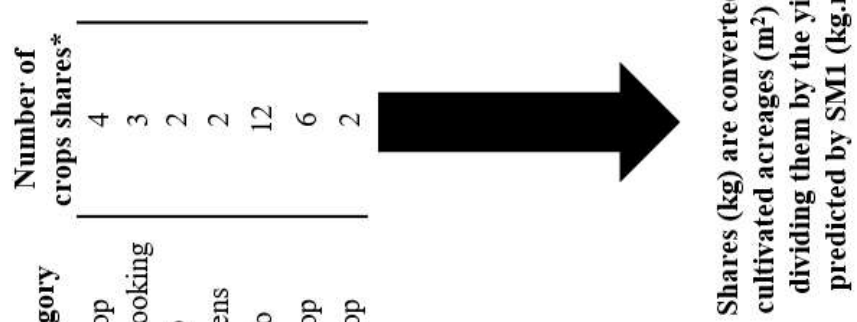

可当票

잉

प०

政

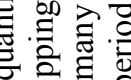

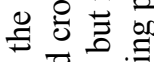

뭉

흥

츨

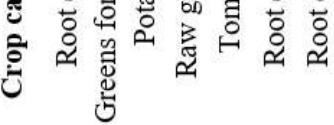

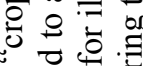

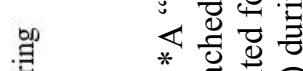

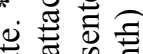

品这

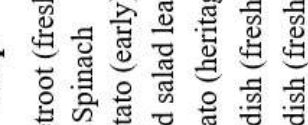

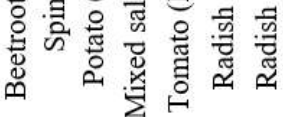

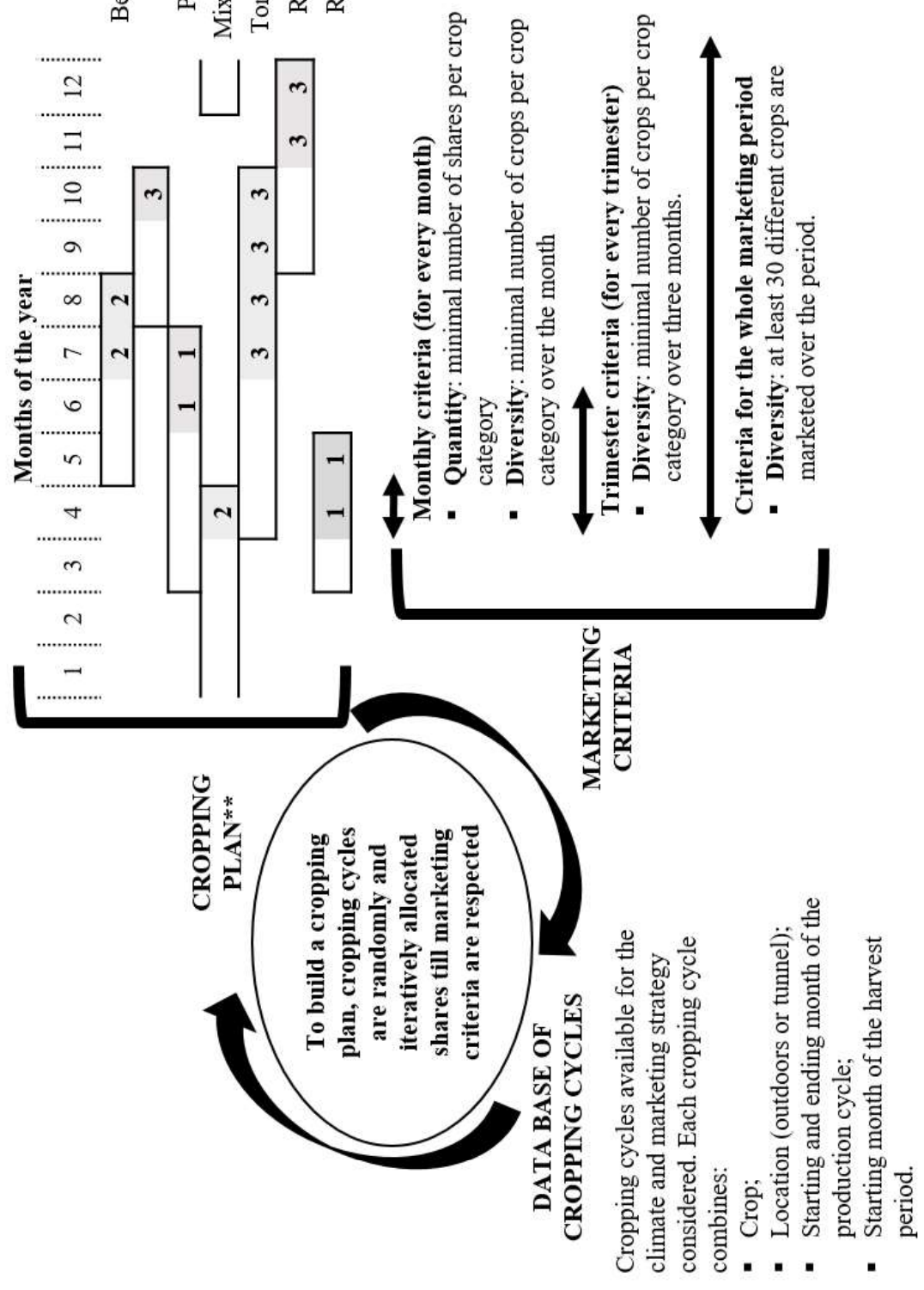

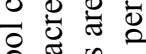

8 o

일

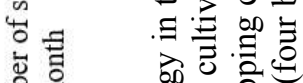

की 0 \%

T્ज :

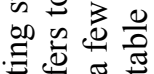

잉

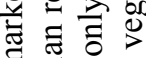

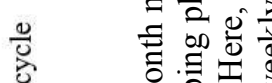

일

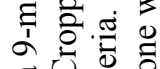

ธี *

๙ิํํㄹ

$\sum_{0}^{\infty} \frac{0}{0}$ 竞

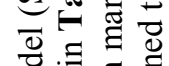

吾:

की

-

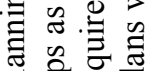

중 융 헌 줄

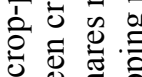

\& के क्ष

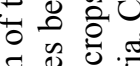

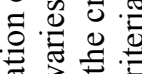

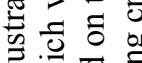

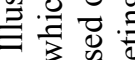

sio

可

劳

$\stackrel{\infty}{\infty} \cong$

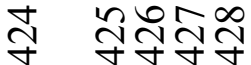




\subsubsection{Conversion of cultivated acreage to utilized agricultural area}

The cultivated acreage of all cropping cycles present each month were summed for the tunnels and the outdoor area. The utilized agricultural area (UAA) was calculated for the outdoor and tunnel areas by dividing the highest monthly cultivated acreage by a parameter called the maximal cropping intensity $(\mathrm{MCI})$, which accounted for the land-use objective of each technical system and integrated the practices of intercropping, growing green manure, and leaving land fallow between cropping cycles. Higher MCI values denote more intensive land use. The range of MCI values for each technical system and location is presented in Table $\mathbf{5}$. For each simulation, a MCI value in tunnel and outdoor areas was randomly drawn from their respective range of values.

\section{Table 5}

Range of maximal cropping intensity (MCI) for different technical systems according to land-use objective.

\begin{tabular}{lllll}
\hline \multirow{2}{*}{ Location } & \multirow{2}{*}{ MCI } & \multicolumn{3}{l}{ Technical system } \\
\cline { 2 - 5 } & & Manual & Bio-intensive & Classic \\
\hline \multirow{2}{*}{ Tunnel } & Min & 1.6 & 1 & 1 \\
\cline { 2 - 5 } & Max & 2 & 1 & 1 \\
\hline $\begin{array}{l}\text { Outdoor } \\
\text { field }\end{array}$ & Min & 1 & 0.6 & 0.4 \\
\cline { 2 - 5 } & Max & 1.4 & 1 & 0.8 \\
\hline
\end{tabular}

The acreage of footpaths between cropping beds was integrated by considering that footpaths represented $20 \%$ of UAA in tunnels and $35 \%$ of UAA outdoors according to farm observations. The global share of tunnels in UAA was calculated.

\subsection{Simulating incomes and utilized agricultural area for a full-time farmer}

\subsubsection{Considering three investment hypotheses for costs and subsidies}

Our model considered that farmers had no initial capital and had to acquire 5-year bank loans to cover the initial investment. Three investment hypotheses were considered in the simulations: (1) In a low-cost setup, the farmer built his equipment (self-built) using secondhand material. This strategy reduced investment costs but increased the production workload; (2) In a high-cost setup, the farmer bought all new equipment. This strategy reduced workload 
but increased investment costs; (3) In the running phase, investment bank loans had been paid off (five years after initial startup).

Costs and subsidies are described in Table $\mathbf{6}$ and Table 7 for a microfarm managed by a

Table 6

Annual global costs, expenses, and subsidies (in EUR) for the three technical systems.

460

\begin{tabular}{|c|c|c|c|c|}
\hline \multicolumn{2}{|c|}{ Technical system } & \multirow{2}{*}{$\begin{array}{l}\text { Manual } \\
11 \% \text { of sales }\end{array}$} & \multirow{2}{*}{$\begin{array}{l}\text { Bio-intensive } \\
11 \% \text { of sales }\end{array}$} & \multirow{2}{*}{$\begin{array}{c}\text { Classic } \\
20 \% \text { of sales }\end{array}$} \\
\hline $\begin{array}{l}\text { Variable } \\
\text { costs }\end{array}$ & $\begin{array}{l}\text { Seeds and plants, fertilizers and } \\
\text { phytosanitary products, other } \\
\text { production supplies, and small } \\
\text { equipment }\end{array}$ & & & \\
\hline \multirow[t]{2}{*}{$\begin{array}{l}\text { Fixed costs } \\
\text { per farm }\end{array}$} & $\begin{array}{l}\text { Water, electricity, fuel, equipment } \\
\text { maintenance, and other expenses } \\
\text { (administrative tasks, organic } \\
\text { certification) }\end{array}$ & 5,000 & 6,500 & \multirow[t]{2}{*}{8,000} \\
\hline & Social security and insurance & & 4,000 in all cases & \\
\hline \multicolumn{2}{|c|}{ Subsidy per farm* } & 2,755 in all cases & & \\
\hline \multicolumn{2}{|c|}{ Subsidy per $\mathrm{m}^{2 *}$} & 0.085 in all cases & & \\
\hline
\end{tabular}

Table 7

Additional costs and subsidies (in EUR) during the setup period.

\begin{tabular}{llllllc}
\hline Technical system & Manual & \multicolumn{2}{c}{ Bio-intensive } & \multicolumn{2}{c}{ Classic } \\
\hline Investment hypothesis & $\begin{array}{l}\text { Low-cost } \\
\text { setup }\end{array}$ & $\begin{array}{l}\text { High cost } \\
\text { setup }\end{array}$ & $\begin{array}{l}\text { Low-cost } \\
\text { setup }\end{array}$ & $\begin{array}{l}\text { High cost } \\
\text { setup }\end{array}$ & $\begin{array}{l}\text { Low-cost } \\
\text { setup }\end{array}$ & $\begin{array}{l}\text { High cost } \\
\text { setup }\end{array}$ \\
\hline Initial fixed investment per farm* & 15,000 & 25,000 & 25,000 & 35,000 & 35,000 & 45,000 \\
\hline $\begin{array}{l}\text { Investment cost per } m^{2} \text { of tunnels with } \\
\text { irrigation }\end{array}$ & 10 & 30 & 10 & 30 & 10 & 30 \\
\hline
\end{tabular}

Investment cost per $\mathrm{m}^{2}$ to buy the 0.5 in all cases

utilized agricultural area

Annual bank loans to pay Initial investment divided by 5 years + annual interest calculated with an

interest rate of $3 \%$.

Annual setup subsidy per farm $\quad 3,000$ in all cases

Investment for 3,000 $\mathrm{m}^{2}$ of land, water drilling, mechanized and manual tools, low-cost delivery van, and small 


\subsubsection{Calculating incomes and utilized agricultural area according to annual workload}

Based on the cropping plan and mean crop prices (Table 2), the global sales value attached to the production of one vegetable box throughout the marketing season was calculated. The workload required to generating these sales value was quantified based on the production workload attached to the different crops predicted by SM2, and considering that administrative and commercial tasks represented $20 \%$ of annual workload. The UAA required for this production had been calculated as above-mentioned based on SM3.

To calculate the global sales and the UAA on the farm, we assumed that the global production of the farm was a linear combination of identical vegetable boxes with similar cropping plans. The number of vegetable boxes produced depended on the global annual workload considered for a single farmer. To calculate incomes, costs and subsidies described in Table 6 and Table 7 were respectively deducted or added to sales, considering the previously determined share of tunnels in UAA (Fig. 1).

\subsection{An application of MERLIN to validate the model}

\subsubsection{Integrating stochasticity in simulations}

To validate the model, we ran simulations for the different climates and contrasted strategic options that were designed with farmers. We considered 3 possible level of annual workload as input variable to cover the diversity observed on the field $(1,800 \mathrm{~h} ; 2,500 \mathrm{~h}$ and $3,000 \mathrm{~h})$. For each combination of technical system ( 3 possible), marketing strategy ( 2 possible), investment hypothesis ( 3 possible), climate ( 2 possible), and level of annual workload ( 3 possible), we ran 1000 simulations leading to $108,000(3 * 3 * 2 * 2 * 3 * 1000)$ simulations. The simulation process is detailed in Fig. 1. A total of 1,000 simulations was implemented for each combination of input variables because the average and median incomes and UAA stabilized after 600 to 850 simulations depending on combinations of input variables. Simulations were not ran to maximize incomes but to the explore the variability of incomes possible over one production 
year due to the variability of yields, workload and cropping plan observed on the field and modelled with SM1, SM2 and SM3. For each simulation, fixed effects of SM1 and SM2 were drawn in the normal distribution of the parameter estimates. Random farm effects and residual effects on yields (Y) and production workload (Wp) were drawn from their normal distributions to integrate farm variability (see Table 3 and Table 4, respectively). Fixed effects, farm effects, and residual effects were added to the predicted effect for each crop (Table 2) to predict yield (Y) and production workload (Wp) according to the selected technical system and investment hypothesis. A cropping plan was randomly generated by SM3 for each simulation.

Our model was stochastic because a given combination of input variables (set of strategic choices, climate, annual workload) led to variable incomes and UAA. We integrated stochasticity to account for the uncertainty that was inherent in the model due to the small number of farms in the sample, and to explore a wide range of possible situations.

\subsubsection{Validating the model}

Modeling outputs are generally validated by comparing fitted values to real values from a large independent data set (Bellochi et al., 2010). Given the fact that microfarms are really innovative and new systems in France, it was impossible to access such large data set. We only managed to obtained data for 12 microfarms not belonging to our sample. We also compared the simulations with the 10 farms from the initial sample to ensure that our modeling hypotheses at different levels of MERLIN accurately represented the initial case studies. MERLIN was a stochastic model that provided a range of values for one set of input variables. Therefore, we considered that visual validation was sufficient to ensure that the real values were contained within this range. A sensitivity analysis was implemented for the major parameters of this model (Appendix B).

The type of validation for models depends on the objective for which the model was developed (Bellochi et al., 2010). In our case, the central objective was to provide insights about 
the effects of different strategies on microfarm incomes and UAA. These simulations and results were targeted for use by microfarmers and public organizations. In agreement with our grounded modeling approach, we considered that the central validation of MERLIN had to come from practitioners (Troitzsch, 2004). MERLIN was presented in ten 2-hours collective workshops with more than 300 practitioners including microfarmers, organic market gardening advisors, and teachers. In each workshop, the architecture and parameters of MERLIN were detailed (e.g. impacts of the different practices on yields, costs, prices, crop planning criteria...) during one hour and modelling outputs were presented during 30 minutes, the last 30 minutes were dedicated to exchanges with practitioners. We used the validation criteria defined by Cash et al. (2003): credibility (scientific adequacy), saliency (relevance to decision makers), and legitimacy (fair and unbiased information that respected stakeholders' values and beliefs).To launch the discussions, we asked the questions: (i) do you think the results are credible? ; (ii) are the modelling outputs useful and why? ; (iii) what would you have expected from the model that is missing ?; (iv) do you trust the results? : (v) what do you think of this research project?. Answers and exchanges stimulated by these questions were analyzed with the same qualitative method used for semi-structured interviews focusing on the validation.

\subsubsection{Statistical analysis of modelling outputs}

Incomes were expressed as incomes per hour labor to compare the performances of farms with different levels of annual workload. Pairwise comparisons of mean levels of income per hour and UAA were performed with t-test (5\%) with unequal variances across simulations.

\section{Results}

\subsubsection{Comparison of predicted outputs with data from actual microfarms}

Comparisons of a sample of simulated outputs and real farm data showed that real farm data were within the same range as the values predicted by MERLIN (Fig.5). The model accounted for the large variability that existed between farms. The relative variations of values depending 
547 on the input variables (patterns) were well represented by the model (Küppers and Lenhard, 548 2005).

549 The UAA was the smallest in the manual system and the highest in the classic system, 550 which was consistent with the relative land use objective of each system: high in the manual 551 system, lower in the classic system and intermediary in the bio-intensive system (Fig.5a).

552 In the running phase, the bio-intensive technical system generated the highest income per 553 hour workload, followed by the manual system and the classic system. In both setup phases 554 (low or high-cost), the manual and bio-intensive systems with less initial investment generated 555 more income that the classic system whose investment was increased by a high level of 556 mechanization. The high-cost setup led to higher levels of incomes that the low-cost setup 557 because the workload the decrease of investment costs allowed by the low-cost strategy did not 558 mitigate the increase of workload due to self-building of equipment (Fig.5c).

559 The 9-month marketing strategy led to higher income than the 12-month strategy because 560 it did not produce winter storage crops, which had lower added value compared with other 561 crops. Climate had no significant impact (5\%) on incomes (Fig.5b). 

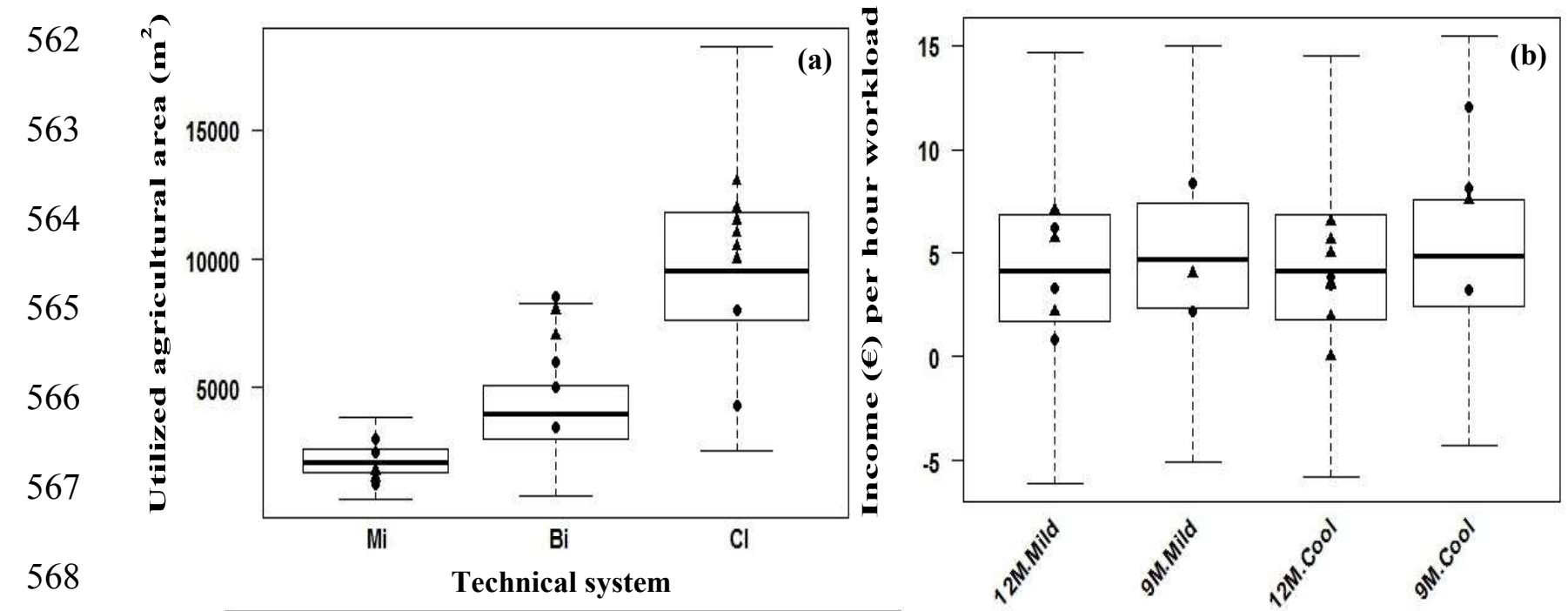

Technical system

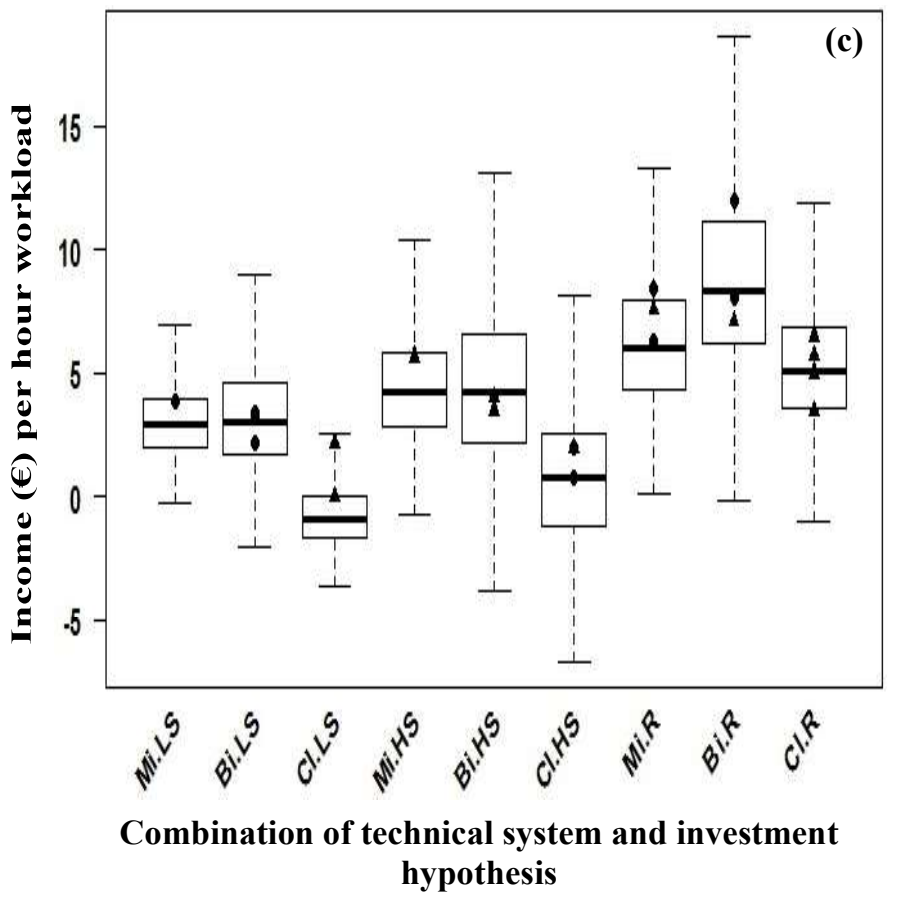

Combination of marketing and climate

Fig. 5. Comparisons of modeling outputs and real data for (a) utilized agricultural area according to the technical system, (b) income per hour workload according to marketing and climatic conditions, and (c) income per hour workload according to the technical system and investment hypothesis. Boxplots are generated by the model. Circles represent average data from the sample (10 data points); triangles represent average data from other farms (12 data points).

Technical systems: Mi, manual microagriculture; $\mathrm{Bi}$, bio-intensive; $\mathrm{Cl}$, classic.

Marketing strategies: 12M, 12-months marketing strategy including winter storage crops; 9M, 9-months marketing strategy excluding winter storage crops. Investment hypotheses: LS, low-cost setup; HS, high-cost setup; R, running phase.

\subsubsection{Practitioner validation of the model}

The MERLIN model was deemed to be credible by practitioners, based on their 
592 The predicted order of magnitude of the income per hour labor and UAA (Fig. 5) were in 593 agreement with practitioners' expectations. However, the extreme values of the boxplots were 594 either overestimates or underestimates (as discussed later). The practitioners considered the 595 model to be salient, as the main issues and questions concerning microfarms were addressed, 596 especially those pertaining to future farmers who wondered whether it was realistic or not to 597 start a microfarm without a tractor and in which extent excluding winter storage crops from 598 marketing or self-building of equipment could improve incomes. The required utilized 599 agricultural area according to strategies was also really expected by future microfarmers as 600 agricultural organizations often advise them to buy more land that they are able or willing to 601 given their limited capital. However, farmers mentioned that they would be interested in 602 investigating in which extent some crop planning configurations would impact income given a 603 set of strategic options, climate and annual workload. So far, we have not analyzed modelling 604 outputs in the light of crop planning configurations but farmers claimed that such type of 605 information would be really useful as a decision support. Further analysis will therefore be 606 carried out in this direction.

607 The model was perceived as legitimate because it was based on farm data that were mostly 608 collected by farmers, designed thanks to farmers' expertise, and participation. Farmers argued 609 that the legitimacy of our approach also relied on the fact that our approach was not perceived 610 as prescriptive because we did not seek to determine an optimal set of strategies but explored 611 contrasted options that decision makers were free to evaluate themselves depending on their 612 objective. 


\section{3 \\ 4. Discussion}

614

615

616

617

618

619

620

622

623

624

625

626

627

628

629

630

631

632

633

634

635

636

637

\subsection{Economic performance of microfarms}

The model application showed that microfarms implementing low-input practices with intense land use (high planting density, more crop successions per plot per year, and intercropping) could potentially generate higher income with less land than microfarms applying classical strategies for organic market gardening. These results are in agreement with some previous studies showing that small farms can be more productive and efficient than bigger farms (Carter, 1984; Rosset, 2000).

Our model results indicate that marketing and investment strategies have key roles in microfarm income, whereas most available information focuses on technical aspects. Future work will explore in greater depth the economic viability of microfarms using the modeling outputs of MERLIN.

\subsection{Limits of the model and perspectives}

The model had low sensitivity to the parameters related to yield (Appendix B). It was highly sensitive to SM2 parameters predicting production workload, price levels, fixed costs, initial investments for tunnels, and setting up subsidies. Further model development will require to carry out more precise measurements of these parameters. Variations of the sensible parameters may be the basis of other scenarios for investigation (e.g., comparing high-selling price and low-selling price scenarios).

The major limit of our model was the limited sample used (10 farms) and the limited independent dataset to validate quantitatively the simulation outputs (12 farms). This difficulty is intrinsically connected to the fact that microfarms are new and innovative farming systems. We developed the MERLIN model to answer the pressing question of microfarms incomes although we were aware of the limited access to data to carry out this study. Our grounded 
638 modelling approach, based on farmer's expertise and participation was a pragmatic solution to overcome this difficulty. We considered that given the lack of data about microfarms, validation

640 by practitioners (more than 300) was the most reliable solution at this stage. However, this 641 advocates for prudence and reserve about the results of our study. The number of microfarms 642 is quickly growing in France and further research should definitely aim to enlarge datasets to 643 calibrate and validate the model, strengthen or mitigate our results.

644 The extreme values predicted by the model resulted from the stochastic logic of randomly 645 drawing fixed-parameter estimates of SM1 and SM2, to account for the uncertainty linked to 646 the limited sample. Collecting more data would allow us to consider the mean parameter 647 estimates and reduce the extreme values of income and UAA that stakeholders judged unrealistic.

649 The data collected to build SM1 and SM2 were mean yields and workload for each crop 650 considering the annual production, workload and cultivated acreages on the farm including 651 tunnels and outdoors area. These mean yields and workload were affected similarly to all possible cropping cycles of a given crop without accounting for possible variability within the year and according to its location (in tunnels or outdoors). This may lead to underestimations of yields in tunnels and overestimations of outdoors yields for crops which are grown both outdoors and in tunnels. Same way, some crops may be more productive in summer than in 656 winter and for a given crop workload may vary depending on the time of the year. Most crops are sold quickly after harvesting but for winter storage crops, storage losses (and therefore marketable yields) may vary depending on the harvest time. As the crop planning sub-model imposes a diversity of crops over the year to match direct-selling marketing requirements, it

660 generates cropping plans where a given crop tends to be grown at different times of the year 661 and in different locations. At the scale of the production year, workload and incomes 
Table 8.

669 Limits of the MERLIN model and further investigation perspectives.

\begin{tabular}{|c|c|}
\hline Limit & Perspective \\
\hline $\begin{array}{l}\text { Estimations of workload per crop relied on } \\
\text { farmers' judgement and are sensitive parameters. }\end{array}$ & Carry out workload measurements on a wider sample of farms. \\
\hline $\begin{array}{l}\text { Most microfarms used to calibrate the data, } \\
\text { whether implementing low-input practices or not, } \\
\text { used plastic mulch to reduce weeding for certain } \\
\text { crops (embodied in the workload, yields and costs } \\
\text { data). The frequency of plastic mulch use varied } \\
\text { between farms and crops. }\end{array}$ & $\begin{array}{l}\text { Collect more data to model the impact of the level of plastic } \\
\text { mulch use on workload, yields, and costs. }\end{array}$ \\
\hline
\end{tabular}

In the studied area, climate only impacts cropping cycle possibilities but not yields.
Collect more data in contrasting climates to characterize the potential impact of climate on yields

\footnotetext{
We assumed that crop diversity resulting from marketing criteria always allowed effective intercropping based on the complementarity of rooting depths, plant heights, and maturing Characterize each of the 50 crops with their rooting depths, heights, and maturation periods to integrate intercropping criteria in crop planning.
} period.

Crop planning only referred to two zones in terms of spatial allocation, outdoors or in tunnels, and did not account for soil specificity.

Rotation criteria were not explicitly considered Further develop a spatially explicit model accounting for soil considering the postulate that direct-selling constraints guaranteed a balance between botanical families at the farm scale.

Climatic and ecological uncertainties or accidents were not considered.
Integrate the possibility of extreme events in the model and discuss adaptation strategies with farmers in simulation-based participatory workshops (Martin et al., 2013). 
Although expert knowledge has been widely used to design specific compartments of simulation models that integrate biophysical and socioeconomic components of farming systems (Rossing et al., 2007), the theoretical basis of simulation models has relied primarily on the integration of academic knowledge from various disciplines (Oriade and Dillon, 1997; Stoorvogel, 2004; Jansen and Van Ittersum, 2007). However, rich academic knowledge is not always available for ROFS, which are often sparse individual initiatives.

Agroecological studies have highlighted the importance of farmer-based innovations for the development of more sustainable food systems (Holt-Giménez and Altieri, 2013). Martin et al. (2013) proposed that simulation models are a valid way to support exploratory innovations if farmers are involved at various steps of the modeling process. In this grounded modeling approach, practitioners were involved in defining the problem to be solved, bringing knowledge and expertise to build the model, and validating it in a pragmatic, interactive, and inductive perspective. This collaboration led to an original model, MERLIN, which addressed the key challenge of crop planning for diversified farms that sell through short supply chains. The challenge of building this kind of model has been qualitatively described (Navarrete, 2009), but to our knowledge, never simulated.

The model enabled exploration of innovative technical systems based on farm data, and examination of low-cost investment strategies that are often encouraged in alternative farmers' networks. When we validated the model with practitioners, we did not ask specific question about the added value of our modelling approach compared to optimization models. Nevertheless, practitioners said spontaneously that they appreciated that we "gave every scenario a chance" and did not seek to identify an optimal set of strategies, which is typical for simulation models relying on linear programming (Rossing et al., 2007). This aspect was central in the legitimacy of our model because radical organic farmers are often reluctant to use topdown and prescriptive approaches. The results of this study, highlighting that low-input 
699

700

701

702

703

704

705

706

707

708

709

710

711

712

713

714

715

716

717

718

719

720

721

practices with intensive land use generate higher income on less land, may have been reached with an optimization approach and could be considered as prescriptive. However, farmers told us that they would prefer sub-optimal set of strategies for other reasons than economic objectives. For example, for some farmers the manual technical system is not an option because they consider than manual labor increases work hardness whereas for other manual labor is preferable to mechanization because they want to "get their hands in the dirt". Investigating and presenting all sets of strategies designed by farmers without aiming to determine an optimal one provides a richer material for further discussions where farmers are free to react and comment the modelling outputs based on other rationalities than just maximizing incomes. Deeper discussions with farmers on a wider sample of modelling outputs, involving other modalities for input variables may open original perspectives for research that may not have come to light while only focusing on the optimal option. Such workshops were developed based on the MERLIN model in and will be presented in a future paper.

In conclusion, we consider that grounded modeling is a promising way to explore innovative ROFS. However, the epistemological and methodological implications of grounded modeling require further investigation. This may benefit from a wider framework of transdisciplinary strategies developed in agroecological studies, which integrate the knowledge of stakeholders and academics using problem-solving approaches (Méndez et al., 2013).

\section{Acknowledgements}

We thank all farmers who dedicated time and energy to this research project. We also thank the Ile-de-France Region for financial support for this work through DIM ASTREA; Agnes Bellec-Gauche for her accountancy skills; and Rodolphe Sabatier and Guillaume Martin for their constructive feedback and support. 
723

724

725

726

727

728

729

730

731

732

733

734

735

736

737

738

739

740

741

742

743

\section{References}

Aubry, C., Christine, Bressoud, F., Frederique, Petit, C., Caroline, 2011. Les circuits courts en agriculture revisitent-ils l'organisation du travail dans l'exploitation?, in: Le travail en agriculture : son organisation et ses valeurs face à l'innovation. Editeur L'Harmattan,

Bates, D.M., 2010. 1me4: Mixed-effects modeling with R. New York: Springer; http://lme4.rforge.r-project.org/lMMwR/lrgprt.pdf

Bellocchi, G., Rivington, M., Donatelli, M., Matthews, K., 2010. Validation of biophysical models: issues and methodologies. A review. Agron. Sustain. Dev. 30, 109-130.

doi:10.1051/agro/2009001

Brisson, N., Bussière, F., Ozier-Lafontaine, H., Tournebize, R., Sinoquet, H., 2004. Adaptation of the crop model STICS to intercropping. Theoretical basis and parameterisation. Agronomie 24, 409-421. doi:10.1051/agro:2004031

Carter, M.R., 1984. Identification of the inverse relationship between farm size and productivity: an empirical analysis of peasant agricultural production. Oxf. Econ. Pap. 36, 131145.

Cash, D.W., Clark, W.C., Alcock, F., Dickson, N.M., Eckley, N., Guston, D.H., Jäger, J., Mitchell, R.B., 2003. Knowledge systems for sustainable development. Proc. Natl. Acad. Sci. 100, 8086-8091. doi:10.1073/pnas.1231332100

Clark, S., Klonsky, K., Livingston, P., Temple, S., 1999. Crop-yield and economic comparisons of organic, low-input, and conventional farming systems in California's Sacramento Valley. Am. J. Altern. Agric. 14, 109-121.

De Liedekerke De Pailhe, A., 2004. Designing intecropping in vegetables, scope for improvements. A case study implemented at Bec Hellouin Farm, Normandy, France. Master 
746 thesis in Organic Agriculture and Agroecolology. ISARA Lyon, France and Wageningen

747 University, $\mathrm{Nl}$.

748 http://www.fermedubec.com/inra/2014\%2009\%20Rapport\%20de\%20stage\%20Alexis\%20de

749 \%20Liedekerke\%20-\%20Associations\%20de\%20cultures.pdf

750 Dogliotti, S., van Ittersum, M.K., Rossing, W.A.H., 2005. A method for exploring sustainable

751 development options at farm scale: a case study for vegetable farms in South Uruguay. Agric.

752 Syst. 86, 29-51. doi:10.1016/j.agsy.2004.08.002

753 Dury, J., Schaller, N., Garcia, F., Reynaud, A., Bergez, J.E., 2012. Models to support

754 cropping plan and crop rotation decisions. A review. Agron. Sustain. Dev. 32, 567-580.

755 Eisenhardt, K.M., 1989. Building theories from case study research. Acad. Manage. Rev. 14, $756 \quad 532-550$.

757 Etienne, M., Du Toit, D.R., Pollard, S., 2011. ARDI: a co-construction method for

758 participatory modeling in natural resources management. Ecol. Soc. 16, 44.

759 Fortier, J.-M., 2014. The Market Gardener: A Successful Grower's Handbook for Small-scale

760 Organic Farming. New Society Publishers, Place of publication not identified.

761 Glaser, B.G., Strauss, A.L., 2009. The discovery of grounded theory: Strategies for qualitative 762 research. Transaction Publishers.

763 GRAB/FRAB (French national federation for organic farming), 2009. S'installer en

764 maraîchage bio. Fiches techniques Fruits et Légumes n¹7.

765 Hervé-Gruyer, P., Hervé-Gruyer, C., 2016. Miraculous Abundance: One Quarter Acre, Two

766 French Farmers, and Enough Food to Feed the World. Chelsea Green Publishing.

767 Holt-Giménez, E., Altieri, M.A., 2013. Agroecology, Food Sovereignty, and the New Green

768 Revolution. Agroecol. Sustain. Food Syst. 37, 90-102. doi:10.1080/10440046.2012.716388 
769

770

771

772

773

774

775

776

777

http://www.agrobio-bretagne.org/wp-content/uploads/2010/09/Installation.pdf (accessed January 23, 2015)

Janssen, S., Van Ittersum, M.K., 2007. Assessing farm innovations and responses to policies: a review of bio-economic farm models. Agric. Syst. 94, 622-636.

Jeunes Agriculteurs (French national syndicate of young farmers), 2013. Enquête nationale sur les hors cadres familiaux en agriculture, qui sont-ils et quels sont leurs besoins? http://www.jeunes-agriculteurs.fr/devenir-agriculteur/item/677-demain-je-serai-paysan-?-etatdes-lieux-des-installations-des-hors-cadres-familiaux (accessed October 12, 2015)

Jones, J.W., Hoogenboom, G., Porter, C.H., Boote, K.J., Batchelor, W.D., Hunt, L.A., Wilkens, P.W., Singh, U., Gijsman, A.J., Ritchie, J.T., 2003. The DSSAT cropping system model. Eur. J. Agron., Modelling Cropping Systems: Science, Software and Applications 18, 235-265. doi:10.1016/S1161-0301(02)00107-7

Keating, B.A., Carberry, P.S., Hammer, G.L., Probert, M.E., Robertson, M.J., Holzworth, D., Huth, N.I., Hargreaves, J.N.G., Meinke, H., Hochman, Z., McLean, G., Verburg, K., Snow, V., Dimes, J.P., Silburn, M., Wang, E., Brown, S., Bristow, K.L., Asseng, S., Chapman, S., McCown, R.L., Freebairn, D.M., Smith, C.J., 2003. An overview of APSIM, a model designed for farming systems simulation. Eur. J. Agron., Modelling Cropping Systems: Science, Software and Applications 18, 267-288. doi:10.1016/S1161-0301(02)00108-9

Küppers, G., Lenhard, J., 2005. Validation of Simulation: Patterns in the Social and Natural Sciences. J. Artif. Soc. Soc. Simul. 8.

Liebman, M., Davis, A.S., 2000. Integration of soil, crop and weed management in lowexternal-input farming systems. WEED Res.-Oxf.- 40, 27-48. 
791 Martin, G., Martin-Clouaire, R., Duru, M., 2013. Farming system design to feed the changing 792 world. A review. Agron. Sustain. Dev. 33, 131-149. doi:10.1007/s13593-011-0075-4

793 Martin, G., Theau, J.-P., Therond, O., Martin-Clouaire, R., Duru, M., 2011. Diagnosis and 794 Simulation: a suitable combination to support farming systems design. Crop Pasture Sci. 62, $795 \quad 328-336$.

796 Méndez, V. E., Bacon, C. M., Cohen, R. (2013). Agroecology as a Transdisciplinary, 797 Participatory, and Action-Oriented Approach. Agroecology and Sustainable Food Systems $798 \quad 37(1), 3-18$.

799 Mendoza, G.A., Prabhu, R., 2006. Participatory modeling and analysis for sustainable forest 800 management: Overview of soft system dynamics models and applications. For. Policy Econ. 801 9, 179-196. doi:10.1016/j.forpol.2005.06.006

802 Miles, M.B., Huberman, A.M., 1984. Qualitative Data Analysis: A Sourcebook Of New 803 Methods. SAGE Publications Inc, Beverly Hills.

804 Morel, K. 2016. Viabilité des microfermes maraîchères biologiques. Une étude inductive 805 combinant méthodes qualitatives et modélisation. PhD dissertation. UMR SADAPT, INRA, 806 AgroParisTech, University Paris-Saclay. http://prodinra.inra.fr/record/387244 (accessed 807 September 14, 2016)

808 Morel, K., Léger, F., 2016. A conceptual framework for alternative farmers' strategic choices: 809 the case of French organic market gardening microfarms. Agroecol. Sustain. Food Syst. 40, $810 \quad 466-492$. doi:10.1080/21683565.2016.1140695

811 Navarrete, M., 2009. How do Farming Systems Cope with Marketing Channel Requirements 812 in Organic Horticulture? The Case of Market-Gardening in Southeastern France. J. Sustain. 813 Agric. 33, 552-565. doi:10.1080/10440040902997785 
814 Olivier de Sardan, J.-P., 2008. La rigueur du qualitatif: les contraintes empiriques de

815 l'interprétation socio-anthropologique. Academia-Bruylant, Louvain-La-Neuve, Belgique.

816 Oriade, C.A., Dillon, C.R., 1997. Developments in biophysical and bioeconomic simulation

817 of agricultural systems: a review. Agric. Econ. 17, 45-58.

818 Pimentel, D., Culliney, T.W., Buttler, I.W., Reinemann, D.J., Beckman, K.B., 1989. Low-

819 input sustainable agriculture using ecological management practices. Agric. Ecosyst. Environ.

$820 \quad 27,3-24$.

821 Pretty, J.N., 1995. Participatory learning for sustainable agriculture. World Dev. 23, 12478221263.

823 Rosset, P., 2000. The multiple functions and benefits of small farm agriculture in the context

824 of global trade negotiations. Development 43, 77-82.

825 Rossing, W.A.H., Zander, P., Josien, E., Groot, J.C.J., Meyer, B.C., Knierim, A., 2007.

826 Integrative modelling approaches for analysis of impact of multifunctional agriculture: A

827 review for France, Germany and The Netherlands. Agric. Ecosyst. Environ.,

828 Multifunctionality of Agriculture: Tools and Methods for Impact Assessment and Valuation

829 120, 41-57. doi:10.1016/j.agee.2006.05.031

830 Stoorvogel, J.J., Antle, J.M., Crissman, C.C., Bowen, W., 2004. The tradeoff analysis model:

831 integrated bio-physical and economic modeling of agricultural production systems. Agric.

832 Syst. 80, 43-66. doi:10.1016/j.agsy.2003.06.002

833 Troitzsch, K.G., 2004. Validating simulation models, in: Proceedings of the 18th European

834 Simulation Multiconference. Erlagen, Germany: SCS, pp. 98-106.

835 Voinov, A., Bousquet, F., 2010. Modelling with stakeholders. Environ. Model. Softw. 25, $836 \quad 1268$ 


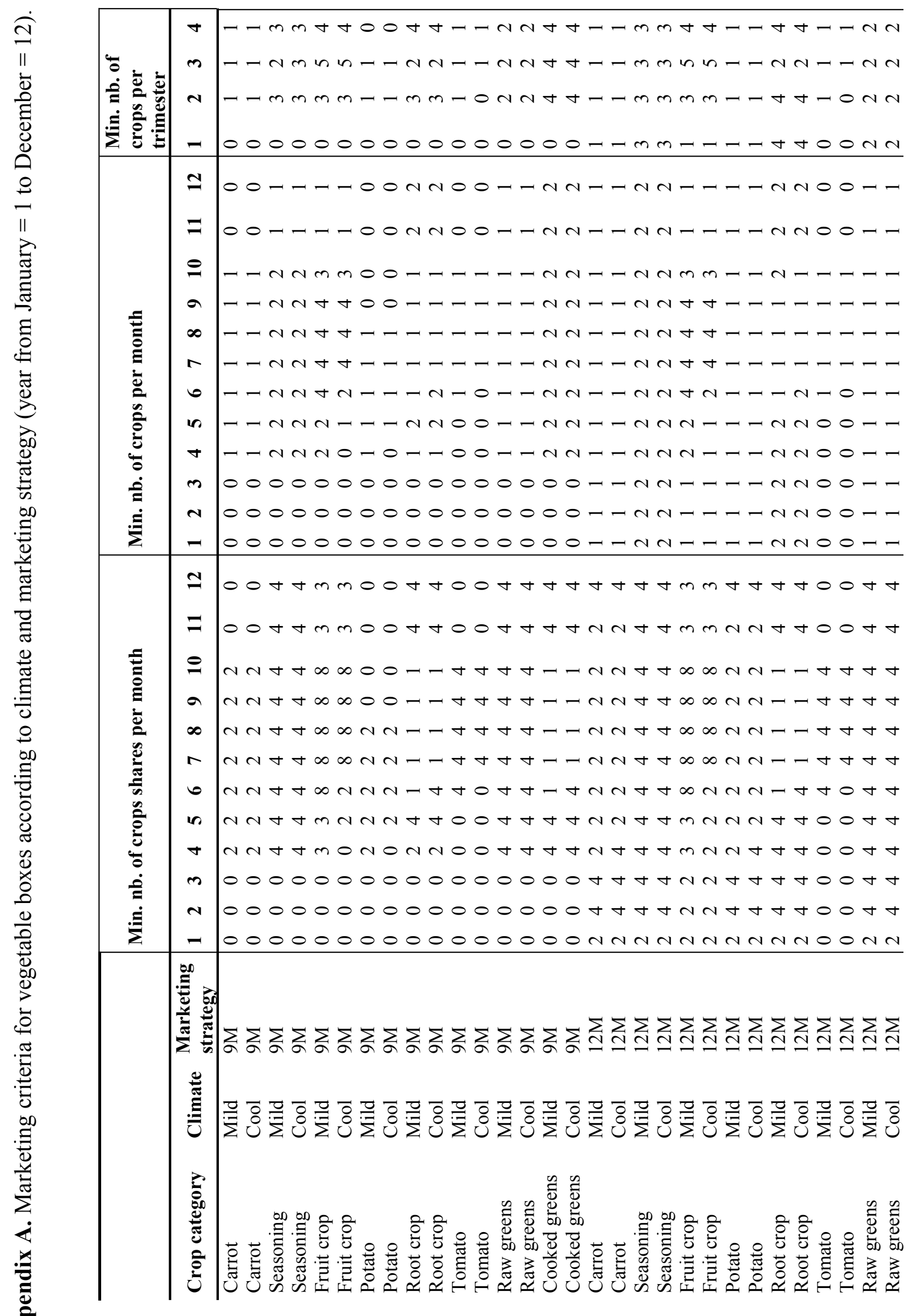




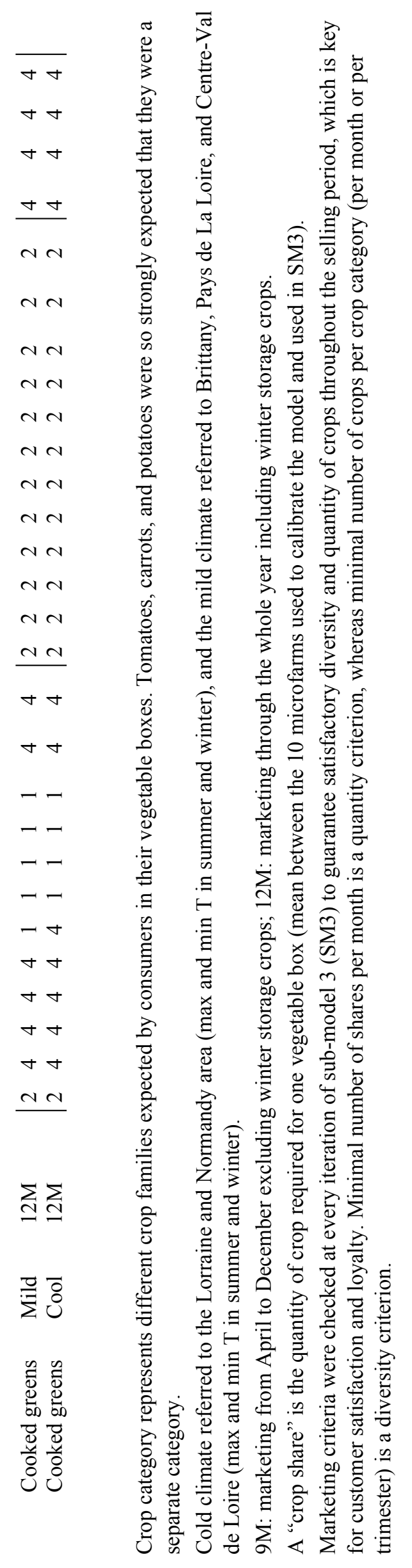


Appendix B. Sensitivity analysis of the MERLIN model

2

\section{Method}

This sensitivity analysis was carried out to identify the effect of the parameters on the model outputs for an annual workload of 2,500h. All parameters were not involved in all scenarios; therefore, the effect of each parameter was analyzed only for the scenarios in which it was involved. Simulations were run increasing or decreasing each parameter value by $10 \%$. The same number of simulations was run as in the paper. For each change in the parameter value, the average income was compared with the mean income of the simulations without change (Figs. B.1 and B.2).

Table B.1.

Parameters considered in the sensitivity analysis from sub-models SM1 and SM2.

\begin{tabular}{|c|c|c|c|c|c|c|}
\hline Name & Description & $\begin{array}{l}\text { Initial } \\
\text { value }\end{array}$ & $\begin{array}{l}\text { Alternative } \\
( \pm 10 \%)\end{array}$ & values & Unit & $\begin{array}{l}\text { Scenarios } \\
\text { used for } \\
\text { analysis }\end{array}$ \\
\hline Ym & $\begin{array}{l}\text { Mean of the intercept of the model } \\
\text { estimating the yield (Y) per square } \\
\text { meter }\end{array}$ & 0.375 & 0.4125 & 0.3375 & $\log \left(\mathrm{kg} \mathrm{m}^{-2}\right)$ & All \\
\hline Y1 & $\begin{array}{l}\text { Mean of the fixed effect of } \\
\text { "motorized labor only for tillage" on } \\
Y\end{array}$ & 0.4811 & 0.52921 & 0.43299 & $\log \left(\mathrm{kg} \mathrm{m}^{-2}\right)$ & $\mathrm{Mi}$ \\
\hline Y2 & $\begin{array}{l}\text { Mean of the fixed effect of "manual } \\
\text { labor only" on Y }\end{array}$ & 0.3216 & 0.35376 & 0.28944 & $\log \left(\mathrm{kg} \mathrm{m}^{-2}\right)$ & $\mathrm{Bi}$ \\
\hline Yf & $\begin{array}{l}\text { Standard deviation of the random } \\
\text { effect of farms on Y }\end{array}$ & 0.1352 & 0.14872 & 0.12168 & $\log \left(\mathrm{kg} \mathrm{m}^{-2}\right)$ & All \\
\hline $\mathrm{Wm}$ & $\begin{array}{l}\text { Mean of the intercept of the model } \\
\text { estimating production workload } \\
\text { (Wp) per square meter }\end{array}$ & 3.0853 & 3.39383 & 2.77677 & $\log \left(\min m^{-2}\right)$ & All \\
\hline Wm1 & $\begin{array}{l}\text { Mean of the fixed effect of } \\
\text { "motorized labor only for tillage" on } \\
\text { Wp }\end{array}$ & -0.3657 & -0.40227 & -0.32913 & $\log \left(\min \mathrm{m}^{-2}\right)$ & $\mathrm{Bi}$ \\
\hline $\mathrm{Wm} 2$ & $\begin{array}{l}\text { Mean of the fixed effect of "manual } \\
\text { labor only" on Wp }\end{array}$ & -0.1159 & -0.12749 & -0.10431 & $\log \left(\min \mathrm{m}^{-2}\right)$ & $\mathrm{Mi}$ \\
\hline $\mathrm{Wm} 3$ & $\begin{array}{l}\text { Mean of the fixed effect of "low- } \\
\text { input practices" on Wp }\end{array}$ & 0.4707 & 0.51777 & 0.42363 & $\log \left(\min \mathrm{m}^{-2}\right)$ & $\begin{array}{l}\text { Bi and } \\
\mathrm{Mi}\end{array}$ \\
\hline Wm4 & $\begin{array}{l}\text { Mean of the fixed effect of "self- } \\
\text { built equipment" on Wp }\end{array}$ & 0.5139 & 0.56529 & 0.46251 & $\log \left(\min \mathrm{m}^{-2}\right)$ & LS \\
\hline Wf & $\begin{array}{l}\text { Standard deviation of the random } \\
\text { effect of farms on } \mathrm{Wp}\end{array}$ & 0.2062 & 0.22682 & 0.18558 & $\log \left(\min \mathrm{m}^{-2}\right)$ & All \\
\hline Yc & $\begin{array}{l}\text { Standard deviation of the random } \\
\text { effects of crops on } \mathrm{Y}^{*}\end{array}$ & 0.6978 & 0.76758 & 0.62802 & $\log \left(\mathrm{kg} \mathrm{m}^{-2}\right)$ & All \\
\hline Wc & $\begin{array}{l}\text { Standard deviation of the random } \\
\text { effects of crops on } \mathrm{Wp}^{* *}\end{array}$ & 0.4623 & 0.50853 & 0.41607 & $\log \left(\min m^{-2}\right)$ & All \\
\hline
\end{tabular}

$15{ }^{*}$ Initial value of the impact of each crop on $\mathrm{Y}$ was increased or decreased, respectively, by $10 \%$. ${ }^{* *}$ Initial value of 16 the impact of each crop on $\mathrm{Wp}$ was increased or decreased, respectively, by $10 \%$. Mi, manual; Bi, bio-intensive. 
Table B.2.

19 Other parameters of the model considered in the sensitivity analysis.

\begin{tabular}{|c|c|c|c|c|c|}
\hline Name & Description & Initial_value & $\begin{array}{l}\text { Alternative } \\
\text { values }\end{array}$ & Unit & $\begin{array}{l}\text { Scenarios used for } \\
\text { analysis }\end{array}$ \\
\hline $\mathrm{P}$ & Crop prices & see Table 2 & \multirow{13}{*}{$\begin{array}{l} \pm 10 \% \text { of the } \\
\text { value of all } \\
\text { parameters }\end{array}$} & EUR kg-1 $^{-1}$ & All \\
\hline MCIt & $\begin{array}{l}\text { Maximal cropping intensity } \\
\text { in tunnels }\end{array}$ & see Table 5 & & $\%$ & All \\
\hline MCIo & $\begin{array}{l}\text { Maximal cropping intensity } \\
\text { outdoors }\end{array}$ & see Table 5 & & $\%$ & All \\
\hline SFt & $\begin{array}{l}\text { Share of footpaths in the } \\
\text { tunnels UAA }\end{array}$ & $20 \%$ & & $\%$ & All \\
\hline SFo & $\begin{array}{l}\text { Share of footpaths in the } \\
\text { outdoors UAA }\end{array}$ & $35 \%$ & & $\%$ & All \\
\hline $\mathrm{VC}$ & Variable costs & see Table 7 & & $\%$ & All \\
\hline $\mathrm{FC}$ & $\begin{array}{l}\text { Fixed costs, social security } \\
\text { and insurance }\end{array}$ & see Table 7 & & $€$ per farm & All \\
\hline FS & Fixed subsidies & see Table 7 & & $€$ per farm & All \\
\hline FM & $\begin{array}{l}\text { Subsidies per square meter } \\
\text { of UAA }\end{array}$ & see Table 7 & & $€ \mathrm{~m}^{-2}$ & All \\
\hline FI & Fixed investment per farm & see Table 8 & & $€$ per farm & HS and LS \\
\hline LI & $\begin{array}{l}\text { Initial investment per square } \\
\text { meter of land }\end{array}$ & see Table 8 & & $€ \mathrm{~m}^{-2}$ & HS and LS \\
\hline $\mathrm{TI}$ & $\begin{array}{l}\text { Initial investment per square } \\
\text { meter of tunnels }\end{array}$ & see Table 8 & & $€ \mathrm{~m}^{-2}$ & HS and LS \\
\hline SS & $\begin{array}{l}\text { Additional subsidies for } \\
\text { setting up per unit area of } \\
\text { land }\end{array}$ & see Table 8 & & $€ \mathrm{~m}^{-2}$ & HS and LS \\
\hline
\end{tabular}

21 HS, high-cost setup; LS, low-cost of setup; UAA, utilized agricultural area.

23 Results

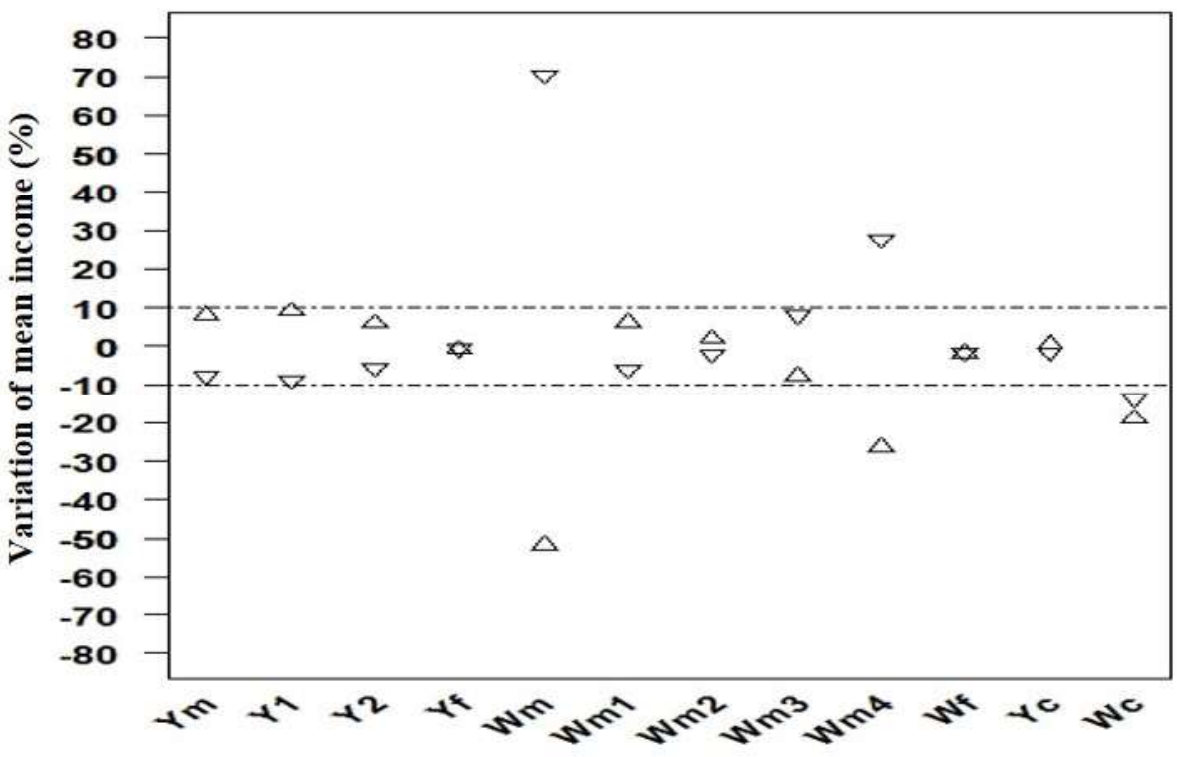

Parameters of the model

Fig. B.1. Variation in mean income caused by variation of parameters from sub-models 1 and 2 with a workload of 2,150 h. Triangles represent a 10\% increase; upside-down triangles represent a $10 \%$ decrease. Only scenarios in which the parameters were involved are presented. 


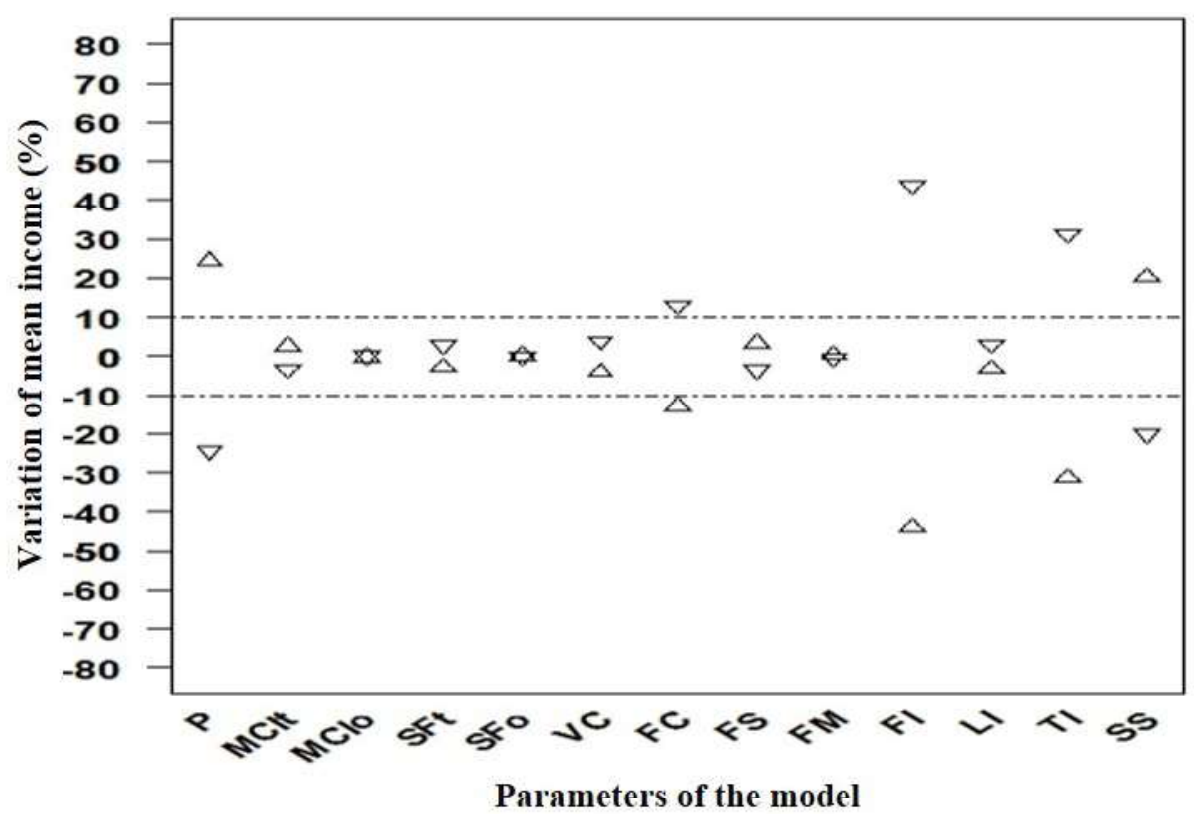

Fig. B.2. Variation in mean income caused by variations of other parameters. Triangles represent a $10 \%$ increase; upside-down triangles represent a $10 \%$ decrease. Only scenarios in which the parameters were involved are presented.

\section{Short note about the impact of prices on incomes}

A variation of $10 \%$ of crops prices can lead to more than $20 \%$ of variation in income because mean incomes have absolute lower values than gross sales (once fixed costs and variable costs have been subtracted to gross sales). A given variation in gross sales is therefore relatively bigger when considered at the income level. For example, if gross sales are 30,000 EUR, an increase of $10 \%$ will lead to 33,000 EUR ( $+3,000$ EUR) of gross sales. If we assume 16,000 EUR of fixed and variable costs, the income will raise from 14,000 EUR $(30,000-16,000)$ to 17,000 EUR (33,000-16,000) which represents an increase of around 21\% in income: $(17,000$ $14,000) / 14,000$. 